\title{
RESPOSTAS MORFOFISIOLÓGICAS DO CAPIM TANZÂNIA (Panicum maximum Jacq. cv. Tanzânia) IRRIGADO À INTENSIDADE DE DESFOLHA SOB LOTAÇÃO ROTACIONADA
}

\author{
ALEXANDRE CARNEIRO LEÃO DE MELLO
}

Tese apresentada à Escola Superior de Agricultura "Luiz de Queiroz", Universidade de São Paulo, para obtenção do título de Doutor em Agronomia, Área de Concentração: Ciência Animal e Pastagens.

P I R A C I C A B A

Estado de São Paulo - Brasil

Abril - 2002 


\title{
RESPOSTAS MORFOFISIOLÓGICAS DO CAPIM TANZÂNIA (Panicum maximum Jacq. cv. Tanzânia) IRRIGADO À INTENSIDADE DE DESFOLHA SOB LOTAÇÃO ROTACIONADA
}

\author{
ALEXANDRE CARNEIRO LEÃO DE MELLO \\ Engenheiro Agrônomo
}

Orientador: Prof. Dr. CARLOS GUILHERME SILVEIRA PEDREIRA

\begin{abstract}
Tese apresentada à Escola Superior de Agricultura "Luiz de Queiroz", Universidade de São Paulo, para obtenção do título de Doutor em Agronomia, Área de Concentração: Ciência Animal e Pastagens.
\end{abstract}

P I R A C I C A B A

Estado de São Paulo - Brasil

Abril - 2002 
Dados Internacionais de Catalogação na Publicação (CIP)
DIVISÃO DE BIBLIOTECA E DOCUMENTAÇÃO - ESALQ/USP

Mello, Alexandre Cameiro Leão de Respostas morfofisiológic as do capim Tanzânia (Pa nic um maximum Jacq. cv. Tanzânia) imigado à intensidade de desfolha sob lotação rotacionada / Alexandre Cameiro Leão de Mello. - - Piracicaba, 2002. $67 \mathrm{p}$.

Tese (doutorado) - Escola Superior de Agric ultura Luiz de Queiroz, 2002. Bibliografia.

1. Capim colonião 2. Desfolha 3. Fisiologia vegetal 4. Imigação 5. Morfologia vegetal 6. Pastagens I. Título

CDD 633.2

\section{"Permitida a cópia total ou parcial deste documento, desde que citada a fonte - $O$ autor"}


Aos meus pais MARGARIDA e ZÉ RICARDO,

pelo exemplo de educação, dedicação e amor aos filhos e, principalmente, pelo infinito incentivo para a realização deste trabalho,

DEDICO

Às minhas avós MARGARIDA E LANDINHA (in memorian), a RICARDINHO, SUSANA, LUCIANA, LORENA, ENRICO, LUIZA e JULIANA, 


\section{AGRADECIMENTOS}

A DEUS, por sempre iluminar meus caminhos.

A Universidade Federal Rural de Pernambuco, pela minha formação profissional.

A Escola Superior de Agricultura "Luiz de Queiroz", pela oportunidade da realização do curso.

A CARLOS G. S. PEDREIRA, pela receptividade, confiança depositada, amizade e, principalmente, pelos ensinamentos e constante troca de conhecimentos.

Aos professores da UFRPE, JOSÉ CARLOS DUBEUX JR., LUIZ G. DA PAZ, MÁRIO DE A. LIRA e MÉRCIA V. F. DOS SANTOS, e ao pesquisador da EMBRAPA/EMPARN, GUILHERME F. DA C. LIMA, pelo grande incentivo dado para a realização deste trabalho.

Ao professor MOACYR CORSI, pela oportunidade de participar desse projeto.

Aos professores MARCOS S. BERNARDES e LÍLIAN AMORIM, pela valiosa contribuição na cessão dos instrumentos de avaliação de campo.

Ao professor VALDO R. HERLING, pela eterna disposição em ajudar no andamento e discussão do trabalho.

A professora TEREZINHA DE J. D. RODRIGUES, pela disponibilidade em contribuir com a realização deste trabalho.

A LILIANE SUGUISAWA, pela amizade e companheirismo, principalmente nos primeiros meses de "Piracicaba".

Aos amigos HENRIQUE MEDEIROS e SÉRGIO FERNANDES, pela amizade e pelo apoio "logístico" na fase final do trabalho. 
A todos os colegas de curso, pela convivência alegre e constante trocas de experiências e conhecimento.

Ao grupo de estagiários do Projeto CAPIM, pela eficiência e disposição na realização de todos os experimentos realizados.

Ao amigo JOSÉ R. LAUREANO FILHO, pela receptividade em Piracicaba e pelas novas amizades adquiridas, que, sem dúvida, contribuíram de forma decisiva na realização deste trabalho.

Aos meus amigos, irmãos de república, ALEYSSON O. PAZA e ALESSANDRO C. DA SILVA, pela paciência mútua, convivência alegre e, principalmente pela forte amizade adquirida não só entre nós, mas com as nossas famílias.

À Fundação de Amparo a Pesquisa do Estado de São Paulo - FAPESP, pela concessão da bolsa de estudos, e pelo suporte financeiro disponibilizado para a execução do trabalho. 


\section{SUMÁRIO}

Página

LISTA DE FIGURAS......................................................................... viii

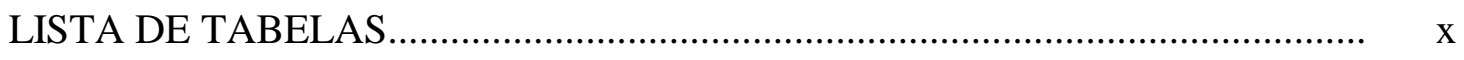

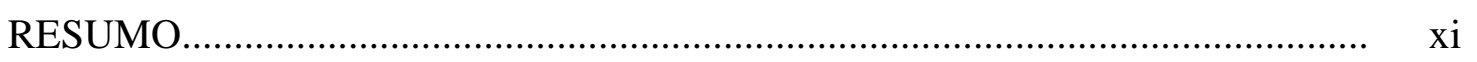

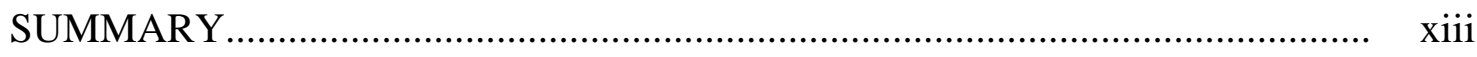

$1 \quad$ INTRODUÇÃO

2 REVISÃO DE LITERATURA...................................................... 3

2.1 Caracterização do Panicum maximum Jacq. cv. Tanzânia.......................... 3

2.2 Potencial produtivo de pastagens tropicais.......................................... 6

2.2.1 Determinantes ambientais da produção primária em estandes de plantas forrageiras................................................................... 8

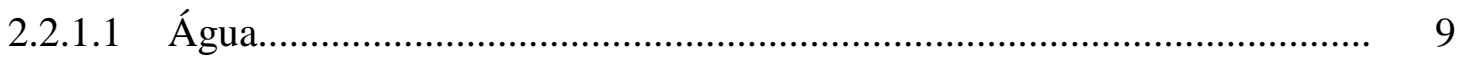

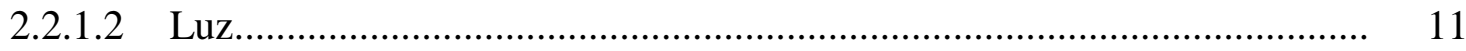

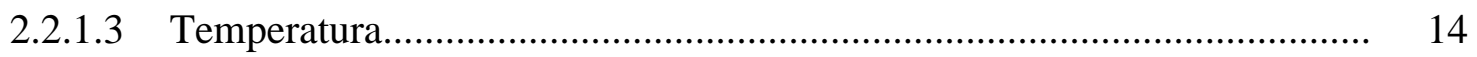

2.2.2 Determinantes morfológicos da produção primária em estandes de plantas forrageiras........................................................... 15

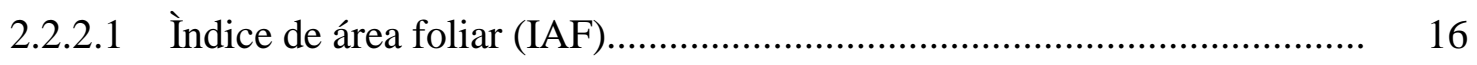

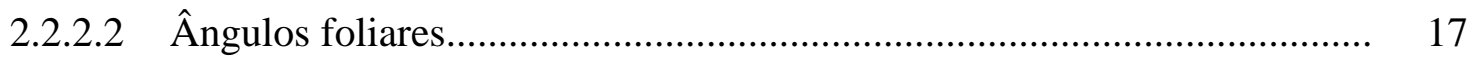

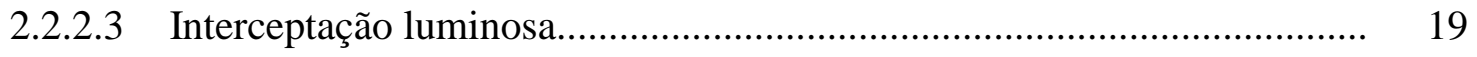

2.2.3 Determinantes fisiológicos da produção primária em estandes de plantas forrageiras.......................................................................... 20

2.2.3.1 Fotossíntese de folhas indivuduais...................................................... 20

2.2.3.2 Fotossíntese de dossel................................................................... 23 
2.2.3.3 Partição de carbono........................................................................... 24

2.3 Altura do dossel e seus efeitos na produção da pastagem.............................. 26

$2.4 \quad$ Irrigação em pastagens................................................................................ 27

3 MATERIAL E MÉTODOS...................................................................... 30

$4 \quad$ RESULTADOS E DISCUSSÃO......................................................... 36

4.1 Altura média do dossel.................................................................. 36

4.2 Fotossíntese foliar líquida e temperatura foliar........................................... 39

$4.3 \quad$ Índice de área foliar (IAF).................................................................. 41

4.4 Ângulos foliares médios....................................................................... 44

4.5 Interceptação luminosa........................................................................ 47

4.6 Acúmulo e taxa de acúmulo líquido de forragem........................................ 50

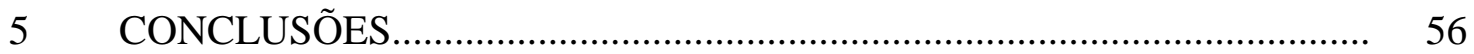

REFERÊNCIAS BIBLIOGRÁFICAS.................................................................. 57 


\section{LISTA DE FIGURAS}

Página

1 Regressões lineares simples observadas para altura média

do dossel entre ciclos de pastejo e dias de observação................................ 36

2 Altura média e interceptação luminosa do dossel de pastagens

de capim Tanzânia ao longo de 8 ciclos de pastejo

(Médias de 3 tratamentos e 4 repetições)................................................... 38

3 Respostas fotossintéticas de folhas (Fotossíntese foliar líquida,

FFL) de capim Tanzânia a ciclos de pastejo na estação

(Média de 3 tratamentos, 4 repetições e 4 datas após o

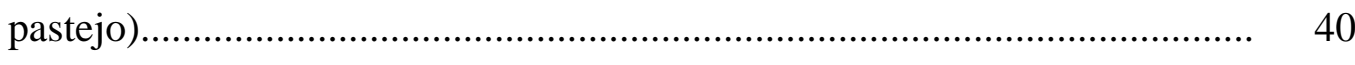

4 Temperaturas médias de folhas de capim Tanzânia

nos ciclos de pastejo durante a estação (Médias

de 3 tratamentos, 4 repetições e 4 datas após o pastejo)............................... 40

5 Índice de área foliar (IAF) de pastos de capim

Tanzânia ao longo de 8 ciclos de pastejo (Média de 4 datas

pós-pastejo e 4 repetições)......................................................................... 42

6 Índice de área foliar (IAF) de pastos de capim Tanzânia

nas 4 datas pós-pastejo (Média de 8 ciclos de pastejo

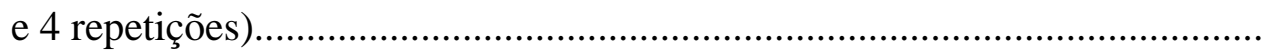

7 Índice de área foliar (IAF) e interceptação luminosa de pastos

de capim Tanzânia ao longo de 8 ciclos de pastejo (Média de 3

tratamentos e 4 repetições) 
8 Ângulo foliar médio de pastos de capim Tanzânia ao longo de 8 ciclos de pastejo (Média de 4 datas pós-pastejo

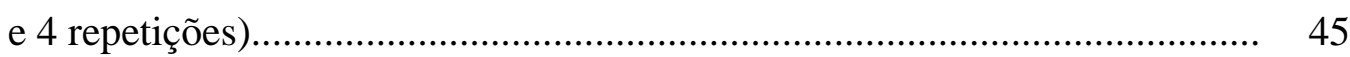

9 Interceptação luminosa (IL) de pastos de capim Tanzânia nas 4 datas pós-pastejo (Média de 8 ciclos de pastejo

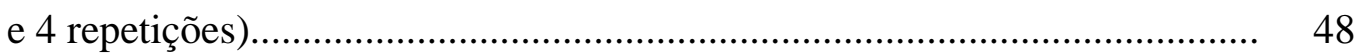

10 Taxa de acúmulo líquido de forragem (TAL) de pastos de capim Tanzânia ao longo de 8 ciclos de pastejo, em três períodos de acúmulo 


\section{LISTA DE TABELAS}

Página

1 Resultado da análise do solo realizada em outubro de 1999 .......................... 30

2 Dados climáticos observados na Fazenda Areão - ESALQ/USP, no período de novembro de 1999 a setembro de 2000,

Piracicaba-SP

3 Regressões lineares de altura média do dossel de capim Tanzânia, em função de dias de rebrota para os

8 ciclos de pastejo (média de 3 tratamentos e 4 repetições)

4 Regressões lineares entre tratamentos e dias de avaliação para índice de área foliar (IAF) de capim Tanzânia

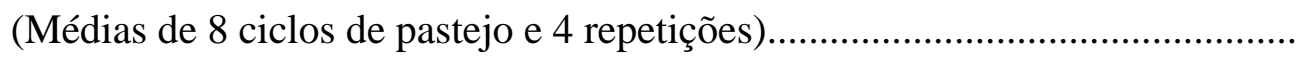

5 Regressões lineares e quadrática entre tratamentos e ciclos de pastejo para ângulos foliares médios de capim Tanzânia (Média de 4 idades de rebrota e 4 repetições)

6 Regressões lineares entre tratamentos, ciclos de pastejo e dias após o pastejo para interceptação luminosa (IL) de capim Tanzânia (Média de 4 repetições) 


\title{
RESPOSTAS MORFOFISIOLÓGICAS DO CAPIM TANZÂNIA (Panicum maximum Jacq. cv. Tanzânia) IRRIGADO À INTENSIDADE DE DESFOLHA SOB LOTAÇÃO ROTACIONADA
}

\author{
Autor: ALEXANDRE CARNEIRO LEÃO DE MELLO \\ Orientador: Prof. CARLOS GUILHERME SILVEIRA PEDREIRA
}

\section{RESUMO}

Os trabalhos de pesquisa não têm dado ênfase à importância das características morfológicas e fisiológicas relacionadas com a produtividade das plantas forrageiras tropicais sob pastejo. Existe a necessidade de se saber como o dossel forrageiro responde a regimes de desfolha, em termos de morfologia de plantas, estrutura do pasto, arquitetura do dossel e de processos fisiológicos como a fotossíntese, para que estratégias ótimas de colheita via pastejo sejam identificadas. O objetivo deste trabalho foi quantificar respostas morfológicas e fisiológicas de dosséis de capim Tanzânia (Panicum maximum Jacq. cv. Tanzânia) sob três intensidades de pastejo, sob lotação rotacionada e irrigação, procurando estabelecer relações causa-efeito não só entre as variáveis estudadas, mas também entre elas e a produção do pasto, medida como acúmulo de massa seca. $\mathrm{O}$ experimento foi conduzido na Fazenda Areão da USP/ESALQ, em Piracicaba, SP, em uma área de 4,8 ha de capim Tanzânia. Os tratamentos foram três intensidades de pastejo, aplicados como quantidades de matéria seca verde residual pós-pastejo $\left(\mathrm{T} 1=1000 ; \mathrm{T} 2=2500\right.$ e T3=4000 $\mathrm{kg} \mathrm{MSV} \mathrm{ha}{ }^{-1}$ ), em um 
delineamento experimental de blocos completos casualizados com quatro repetições. Durante oito ciclos de pastejo (rebrotas de 33 dias após três dias de pastejo em cada ciclo), foram realizadas avaliações de altura média do dossel, índice de área foliar (IAF), interceptação luminosa (IL), ângulos foliares médios, fotossíntese foliar líquida (FFL) e temperatura foliar (TF), em quatro dias dentro do período de rebrota (1, 11, 22 e 33 dias após a saída dos animais). A massa de forragem foi estimada pré- e pós-pastejo em um experimento acompanhante e, com os valores de massa, foram calculados o acúmulo e a taxa de acúmulo de forragem. Calibrações de massa versus altura do dossel nessas datas, foram usadas para estimar as massas nos quatro momentos do período de rebrota. A análise de correlações parciais indicou correlações entre altura e MF, altura e IL, IAF e IL, e ângulos foliares e MF. Com o progresso da estação de pastejo, da primaveraverão para outono-inverno houve reduções nas taxas de FFL, TF e IAF médio. Valores médios de IAF crítico (95\% IL) foram de 3,3 (T1), 3,8 (T2) e 4,2 (T3), alcançados por volta do $22^{\circ}$ dia das rebrotas. Não houve diferença entre tratamentos para taxa de acúmulo líquido de forragem (média $=88,7 \mathrm{~kg} \mathrm{MS} \mathrm{ha}^{-1} \mathrm{~d}^{-1}$ ) nem para acúmulo total de forragem $\left(\right.$ média $=21652 \mathrm{~kg} \mathrm{MS} \mathrm{ha}^{-1}$ acumulado nos 8 ciclos de pastejo). A maior intensidade de pastejo (menor resíduo) alterou a estrutura da pastagem no que diz respeito à arquitetura do dossel, evidenciada pela redução nos ângulos foliares médios (folhas mais planas) ao longo das estações, com plantas passando a interceptar mais luz por unidade de área foliar. Os IAFs críticos medidos sugerem a necessidade de períodos de descanso relativamente curtos em pastos de capim Tanzânia, submetidos a pastejo intensivo sob lotação rotacionada e irrigação. A maior intensidade de pastejo também não causou depressão no vigor de rebrota medido como a taxa de acúmulo líquido de forragem. É necessário, entretanto, avaliar a persistência e perenidade de pastagens de capim Tanzânia manejadas com altas intensidades de pastejo, a longo prazo. O manejo da pastagem em sistemas intensivos de produção, deve buscar níveis de resíduos póspastejo que permitam altas taxas iniciais de acúmulo líquido de forragem. 


\title{
MORPHOLOGICAL AND PHYSIOLOGICAL RESPONSES OF IRRIGATED TANZANIA GRASS (Panicum maximum Jacq. cv. Tanzania) TO GRAZING INTENSITY UNDER ROTATIONAL STOCKING
}

\author{
Author: ALEXANDRE CARNEIRO LEÃO DE MELLO \\ Adviser: Prof. CARLOS GUILHERME SILVEIRA PEDREIRA
}

\section{SUMMARY}

Research has often not emphasized the importance of morphological and physiological traits that are related to the productivity of tropical forages under grazing. There is a need for clarification on how does the sward respond to specific defoliation regimes, in relation to plant morphology, sward structure and architecture, as well as physiological processes such as photosynthesis, so that optimum grazing methods can be devised. The objective of this research was to quantify morphological and physiological responses of Tanzania grass (Panicum maximum Jacq. cv. Tanzania) under three grazing intensities in an irrigated, rotationally stocked setting, in order to establish cause-effect relationships not only among the variables under study, but also between each of them and pasture productivity, expressed as forage dry mass accumulation. The experiment was conducted at Fazenda Areão of USP-ESALQ, in Piracicaba, SP, on a 4,8-ha pasture of Tanzania grass. Treatments consisted of three grazing intensities, represented by three post-graze forage masses $(\mathrm{T} 1=1000, \mathrm{~T} 2=2500$, and $\mathrm{T} 3=4000 \mathrm{~kg}$ green dry mass ha

${ }^{1}$ ), in a randomized complete block design with four replications. During the grazing season (eight 36-d cycles; $3 \mathrm{~d}$ grazing followed by $33 \mathrm{~d}$ rest) the following measurements were taken: mean sward height, leaf area index (LAI), light interception 
(LI), mean leaf angles, net leaf photosynthesis (NLP), and leaf temperature (LT), all measured on four occasions $(1,11,22$, and 33 days after grazing was terminated) of each rest period. Forage mass (FM) was measured in a companion study and mass values were used to calculate forage accumulation and accumulation trates. Calibrations were done between forage mass and sward height and used to estimate mass from height during the regrowth phase. Partial correlation analysis indicated the existence of correlations between height and FM, height and LI, LAI and LI, and leaf angles and FM. As the grazing season progressed from spring-summer to autumn-winter, NLP rates, LT, and mean LAI declined. Mean critical LAI (95\% LI) was 3.3 (T1), 3.8 (T2), and 4.2 (T3) and was always reached around the 22nd day after grazing. No differences were found in forage accumulation rate (mean $=88.7 \mathrm{~kg}$ dry matter $\mathrm{ha}^{-1} \mathrm{~d}^{-1}$ ) or in total seasonal accumulation $\left(\right.$ mean $=21652 \mathrm{~kg} \mathrm{DM} \mathrm{ha}^{-1}$ ) among treatments. Over the season, hard grazing (lower residual mass) altered the sward structure causing shifts in plant architecture, as shown by reduced (more horizontal) leaf angles, as plants begun to intercept more light per unit of leaf area. Critical LAI values suggest that relatively short rest periods may be advantageous for Tanzania grass pastures managed intensively under rotational stocking and irrigation. Hard grazing (1000 kg residual green dry matter $\mathrm{ha}^{-1}$ ) also did not depress regrowth vigor, measured as mean forage accumulation rate. There is a need, however, to assess the long-term persistence of these intensively managed, heavily grazed pastures. Grazing management in these intensive systems should aim at post-graze forage masses that allow for maximum accumulation rates in early regrowth. 


\section{INTRODUÇÃ̃O}

No Brasil, os sistemas de produção animal são caracterizados fundamentalmente pela utilização de pastagens como fonte principal de alimento para os rebanhos. Esses sistemas de produção são, entretanto, tradicionalmente desprovidos de planejamento e controle, sendo, em consequiência, pouco eficientes em termos de produtividade, apresentando, de maneira geral, custos de produção elevados. Não obstante, Faria et al. (1996) citaram que o Brasil apresenta condições muito favoráveis à exploração de bovinos em sistemas que utilizam pastagens. Estima-se que os pastos ocupem cerca de $76 \%$ da superfície utilizada pelo setor agropecuário, o que corresponde a $20 \%$ da área total do país (Brasil, 1994), além de ser detentor do maior rebanho bovino comercial do mundo (FNP, 2001).

Apesar do grande potencial das espécies forrageiras tropicais, a produção forrageira, o valor nutritivo e a qualidade da forragem produzida, as taxas de lotação praticadas, o desempenho e a produtividade animal apresentados pela agropecuária brasileira são bastante inferiores aos níveis possíveis de serem obtidos, tanto do ponto de vista biológico como do ponto de vista operacional. Pesquisas que visam identificar os pontos de estrangulamento desses sistemas de produção têm potencial para embasar o aumento da eficiência e da viabilidade do processo produtivo, já que o pasto é a forma mais econômica de alimentação animal.

O conceito de especialização da pecuária envolve a utilização de rebanhos de alta produtividade e a adoção de técnicas de manejo apuradas, tendo em vista elevar a capacidade de suporte dos pastos, a eficiência de utilização de forragem, assim como reduzir o custo de produção e ainda permitir a diversificação da atividade. Para isso, faz-se necessário uma mudança cultural e estrutural de conceitos, a fim de se realizar 
uma exploração racional das pastagens que permita aumento da competitividade no sistema produtivo (Silva \& Pedreira, 1997). Essa mudança de conceitos passa pelo entendimento de que, para se obter um manejo racional de pastagens, é fundamental o conhecimento da planta forrageira, de sua morfologia, fisiologia e, principalmente, a maneira como interage com o meio ambiente característico de uma pastagem, o ecossistema da pastagem.

A maioria dos trabalhos realizados com plantas forrageiras tropicais não tem levado em consideração atributos relacionados à planta nem a natureza dinâmica do ecossistema. As pesquisas não têm dado ênfase a importância dos parâmetros morfológicos e fisiológicos dessas espécies, havendo, portanto, a necessidade do conhecimento de dados resultantes da avaliação da influência desses parâmetros na rebrota e na produção de massa seca das plantas forrageiras tropicais, quando manejadas sob pastejo.

Diante do exposto, o objetivo deste trabalho foi identificar propriedades morfofisiológicas das plantas e da comunidade vegetal que estão melhor relacionadas com o vigor de rebrota e a produtividade, em resposta à intensidade de desfolha, em pastos de capim Tanzânia (Panicum maximum Jacq. cv. Tanzânia) sob lotação rotacionada e com uso de irrigação. 


\section{REVISÃO DE LITERATURA}

\subsection{Caracterização do Panicum maximum Jacq. cv. Tanzânia}

As plantas do gênero Panicum pertencem à família Gramineae, tribo Paniceae, que possui cerca de 81 gêneros e mais de 1.460 espécies. Encontram-se distribuídas em uma ampla faixa do globo terrestre, desde $40^{\circ} \mathrm{S}$ até $50^{\circ} \mathrm{N}$ de latitude, com predominância na zona equatorial úmida $\left(20^{\circ} \mathrm{N}\right.$ a $\left.20^{\circ} \mathrm{S}\right)$, que corresponde à regiões como a África, Américas Central e do Sul, norte da Austrália, Índia, sudeste da Ásia e as Ilhas do Pacífico, numa altitude de até 2.000 metros (Rocha, 1991).

A espécie Panicum maximum Jacq. tem seu centro de origem na África tropical, sendo encontradas formas nativas até a África do Sul, apresentando-se como uma espécie pioneira ocupando o solo recém-desmatado e em pastagens sob sombra de árvores; porém, é na região leste africana que se encontra o maior potencial de diversidade da espécie (Jank, 1995).

Há na literatura mais de uma versão sobre a introdução de $P$. maximum Jacq. no Brasil. Segundo Chase (1944), ocorreu através da importação de escravos africanos. O capim era utilizado como camas dos navios, logo se estabelecendo nas regiões onde os navios eram descarregados. Depois, o vento, os pássaros, os próprios escravos e outras pessoas se encarregavam, sem que fosse o propósito, de sua disseminação pelo país. Os dados sobre área ocupada pela espécie no Brasil nem sempre são precisos. Esta espécie difundiu-se rapidamente pela região noroeste do estado de São Paulo, sendo um dos mais valiosos contribuintes para a manutenção dos rebanhos nas épocas de escassez de alimentos, representando, no final da década de 1970, 32\% da área de pastagens neste estado (Aronovich, 1995). 
Panicum maximum Jacq. sempre despertou muito interesse entre pesquisadores e produtores devido a sua alta produtividade e ampla adaptabilidade. A partir da década de 1960, vários acessos foram colhidos em diversos países e grandes coleções foram avaliadas (Jank, 1995). Por meio de convênio firmado em 1982 entre a Empresa Brasileira de Pesquisa Agropecuária (EMBRAPA) e o Institut Français de Recherche Scientifique pour le Développment en Coopération (ORSTOM), o Centro Nacional de Pesquisa de Gado de Corte (CNPGC) recebeu uma coleção de P. maximum Jacq. composta por 426 acessos apomíticos e 417 plantas sexuais. Os objetivos do CNPGC eram selecionar os melhores cultivares, visando lançamento direto aos produtores, descrever a variabilidade da coleção para utilização em programas de melhoramento genético e determinar os progenitores masculinos para o início de um programa de melhoramento.

Como resultado desse programa, o CNPGC lançou, em 1990, o cultivar Tanzânia-1 e, três anos depois, o cultivar Mombaça. Esses dois cultivares apresentam algumas diferenças agronômicas em relação aos cultivares testemunhas Colonião e Tobiatã (Jank, 1995). O Tanzânia-1 apresentou superioridade em relação ao Colonião em algumas características avaliadas, apresentando produtividade $86 \%$ maior (26 t MS $\mathrm{ha}^{-1}$ ) do que a do Colonião (14 $\mathrm{t} \mathrm{MS} \mathrm{ha}^{-1}$ ), vigor de rebrota $70 \%$ superior e $29 \%$ a mais em percentagem de folhas. A distribuição da produção ao longo do ano também foi mais uniforme do que a do Colonião e semelhante à do Tobiatã. Apesar de todos os cultivares sofrerem redução na produção de um ano para outro (se os nutrientes exportados não forem repostos), o Tanzânia-1 reduziu sua produção em $48 \%$ enquanto que o Colonião reduziu em 65\%. O Tanzânia-1 também produziu mais no solo adubado, além de perder menos quando sem adubação (21\% a menos, enquanto que o Colonião perdeu 50\%), indicando que, apesar de exigente em fertilidade do solo, é menos sensível que o Colonião.

Quanto à diferenças morfológicas entre o Tanzânia-1 e o Colonião, Jank (1995) demonstrou que o novo cultivar apresenta menor porte, folhas mais finas e decumbentes, espiguetas com maior quantidade de manchas roxas e, portanto, apresentando inflorescências com aspecto bastante roxo, colmos glabros e não cerosos. Em função 
das características apresentadas pelo cultivar, a autora citou que este pode ser mais fácil de ser manejado. Por seu menor porte e abundância de folhas, permite um pastejo uniforme em toda a área, sem o perigo de acúmulo de reboleiras rejeitadas pelos animais.

Tanto o cultivar Mombaça como o Tanzânia-1 vêm sendo implantados em sistemas intensivos de produção, geralmente com altos níveis de adubação, lotação rotacionada e, em alguns casos, uso de irrigação, visando elevados índices de produtividade (Jank, 1994; Euclides et al., 1995; Müller, 2000). Entretanto, poucos dados ainda são disponíveis na literatura a respeito do manejo das pastagens, desempenho e produtividade animal nesses sistemas.

Euclides et al. (2000) compararam adaptação e produtividade de três cultivares de $P$. maximum, quanto ao desempenho e produtividade animal. Os cultivares Tanzânia e Mombaça permitiram maiores desempenhos $\left(455\right.$ e $445 \mathrm{~g}$ novilho ${ }^{-1}$ dia $^{-1}$, respectivamente) e produtividades (725 e $700 \mathrm{~kg} \mathrm{ha}^{-1} \mathrm{ano}^{-1}$, respectivamente) ao longo do ano, de garrotes com PV médio de $250 \mathrm{~kg}$, quando comparados ao cultivar Massai (270 $\mathrm{g}$ novilho $^{-1} \mathrm{dia}^{-1}$ e $620 \mathrm{~kg} \mathrm{ha}^{-1} \mathrm{ano}^{-1}$ ).

Aguiar (2000) relatou, para gramíneas do gênero Panicum, que valores de massa seca residuais entre 1.500 e $2.500 \mathrm{~kg} \mathrm{MS} \mathrm{ha}^{-1}$, provavelmente sejam suficientes para obter-se um desempenho animal satisfatório, sem que as perdas de forragem sejam elevadas, permitindo níveis satisfatórios de reservas fisiológicas para a rebrota das plantas. $\mathrm{O}$ autor relatou, ainda, que em sistemas com altos níveis de adubação, as quantidades de massa seca residuais devem ser mais baixas para que permitam a penetração de luz na base da touceira como forma de estimular o perfilhamento basal, já que esta é a base de exploração para rebrotas vigorosas em sistemas intensivos utilizando essas gramíneas.

Maraschin (1986) afirmou que o sistema de lotação rotacionada não supera o de lotação contínua em desempenho animal (ganho animal ${ }^{-1}$ ), mas tem condições de manter uma lotação mais alta. Segundo o autor, no Brasil, sistemas rotacionados superam os contínuos em $20 \%$ em produtividade. Corroborando essas afirmativas, Aguiar (1997) citou dados coletados em projetos implantados no Brasil Central sob lotação 
rotacionada, onde a taxa de lotação tem aumentado de 50 a $100 \%$ em pastagens de $P$. maximum, após cinco anos de experimento.

Barbosa et al. (2000) conduziram trabalho para avaliar o efeito de níveis de oferta de forragem de capim Tanzânia no desempenho de garrotes nelore. Os níveis de oferta foram 3, 7, 11 e $15 \mathrm{~kg}$ MS de folhas $100 \mathrm{~kg} \mathrm{PV}^{-1} \mathrm{dia}^{-1}$ (\% PV). Os resultados indicaram maior ganho de peso médio diário (em torno de $1,0 \mathrm{~kg}$ ) para a oferta de $11 \%$ e menor (em torno de 0,6 kg) para a oferta de 3\%. Os autores concluíram que pastagens de capim Tanzânia não fertilizadas, aparentemente, devem ser manejadas para ofertas de forragem entre 7 e $11 \%$ PV para altos desempenhos individuais.

Simulações realizadas por Aguiar (2000) revelaram o potencial de produtividade de leite em pastagens de gramíneas do gênero Panicum. Explorando uma produtividade média da pastagem de $37.000 \mathrm{~kg} \mathrm{MS} \mathrm{ha} \mathrm{ano}^{-1}$ instalada em $70 \%$ da área da propriedade, mais 30\% com capineira ou cana-de-açúcar, seria possível alcançar índices como taxa de lotação média de 5,77 UA ha ${ }^{-1}$, taxa de lotação de vacas em lactação de 3 vacas ha ${ }^{-1}$, produções de leite de $10 \mathrm{~L} \mathrm{vaca}^{-1} \mathrm{dia}^{-1}, 30 \mathrm{~L} \mathrm{ha}^{-1} \mathrm{dia}^{-1}$ e $11.000 \mathrm{~L} \mathrm{ha}^{-1} \mathrm{ano}^{-1}$, valores bem acima das médias da pecuária leiteira nacional.

\subsection{Potencial produtivo de pastagens tropicais}

As espécies forrageiras tropicais $\left(\mathrm{C}_{4}\right)$ superam as de clima temperado $\left(\mathrm{C}_{3}\right)$ quanto à capacidade fotossintética, taxa de acúmulo de forragem e eficiência no uso de água e nutrientes (Ludlow, 1985). Agata et al. (1985) também relataram um ponto de saturação luminosa e taxa fotossintética superiores para as gramíneas $\mathrm{C}_{4}$ em relação às $\mathrm{C}_{3}$, tendo encontrado que, em média, a eficiência no uso de água nas tropicais é o dobro da encontrada nas temperadas. Kephart et al. (1992), avaliando a produção de massa seca, peso de perfilhos e taxa de acúmulo de forragem em gramíneas $\mathrm{C}_{3}$ e $\mathrm{C}_{4}$, observaram respostas para esses parâmetros de duas a três vezes maiores nas tropicais. Enquanto o potencial produtivo máximo de forrageiras de clima temperado está limitado a aproximadamente $25.000 \mathrm{~kg} \mathrm{MS} \mathrm{ha}{ }^{-1}$ ano $^{-1}$, produtividades superiores a $80.000 \mathrm{~kg} \mathrm{MS}$ $\mathrm{ha}^{-1}$ ano $^{-1}$ têm sido mencionadas para gramíneas tropicais (Cooper, 1970). 
O potencial de produção é a máxima produtividade biológica obtida sob condições ideais. A genética da planta define o potencial produtivo, enquanto que o manejo é responsável pela expressão dessa característica. Desse modo, estudos sobre o potencial produtivo envolvem análises sobre seleção e melhoramento genético e de práticas de manejo (Corsi \& Santos, 1995).

O potencial produtivo do Panicum maximum está ainda por ser atingido (Corsi \& Santos, 1995), visto que trabalhos do CNPGC apresentaram dados que cerca de $50 \%$ de 156 ecotipos avaliados, são mais produtivos que o Colonião. Relatos de Jank (1994) sobre o potencial desta espécie indicam que um híbrido de P. maximum produzido na Costa do Marfim atingiu produções de matéria seca $140 \%$ mais elevadas do que as plantas progenitoras. Esse híbrido produziu $80 \%$ a mais de matéria seca do que o Tobiatã, o capim mais produtivo naquelas condições.

Dentre as características agronômicas do Panicum, as que impõem maiores restrições a sua produtividade são aquelas relacionadas às exigências edafoclimáticas (Silva, 1995). A amplitude em que esta espécie é produtiva é muito abrangente, havendo relativamente pouca limitação quanto à adaptação da espécie em relação a altitude, precipitação, temperatura, etc. Quanto à fertilidade de solo, é reconhecido que gramíneas desse gênero são bastante exigentes. Entretanto, Sanchez \& Salinas (1981), demonstraram que o Colonião suporta níveis de saturação por alumínio acima de $72 \%$.

Resultados do programa de melhoramento genético do CNPGC revelaram que a média de produtividade de massa seca ha $^{-1}$ ano $^{-1}$, dos melhores ecotipos de Panicum avaliados, foi de $44.000 \mathrm{~kg}$, quando adubados, e $36.000 \mathrm{~kg}$, sem adubação. Nas áreas adubadas, a melhor produtividade foi de $53.000 \mathrm{~kg} \mathrm{MS} \mathrm{ha}^{-1} \mathrm{ano}^{-1} \mathrm{e}$, nas não adubadas, $44.000 \mathrm{~kg} \mathrm{MS} \mathrm{ha}^{-1} \mathrm{ano}^{-1}$. O cultivar Tanzânia-1 produziu cerca de $80 \%$ a mais de massa seca foliar do que o Colonião, com uma produção de matéria seca total de $25,6.000 \mathrm{~kg}$ $\mathrm{ha}^{-1}$ ano $^{-1}$. Foram observadas taxas de acúmulo de 73 e $87 \mathrm{~kg} \mathrm{MS} \mathrm{ha}^{-1} \mathrm{dia}^{-1}$ na época das “águas”, respectivamente para os cultivares Mombaça e BRA-00712, enquanto que na época "seca" estas taxas estiveram por volta de $40 \mathrm{~kg} \mathrm{MS} \mathrm{ha}^{-1} \mathrm{dia}^{-1}$. Herling et al. (1995) observaram taxas de crescimento diário de Colonião ao redor de $89 \mathrm{~kg} \mathrm{MS} \mathrm{ha}^{-1}$ $\mathrm{dia}^{-1}$, com esses valores atingindo $105 \mathrm{~kg} \mathrm{MS} \mathrm{ha}{ }^{-1} \mathrm{dia}^{-1}$, quando a forragem foi colhida a 
cada sete semanas, com um nível de adubação de $320 \mathrm{~kg} \mathrm{~N} \mathrm{ha}^{-1}, 150 \mathrm{~kg} \mathrm{P}_{2} \mathrm{O}_{5} \mathrm{ha}^{-1}$ e saturação por bases de $60 \%$.

Para Corsi \& Santos (1995), o potencial de produtividade biológica do $P$. maximum pode ser expresso através de elevada eficiência de pastejo associada à combinação das curvas de estacionalidade de produção de forragem e de estacionalidade de exigência nutricional do rebanho, quando a espécie for explorada em solos de elevada fertilidade.

\subsubsection{DETERMINANTES AMBIENTAIS DA PRODUÇÃO PRIMÁRIA EM ESTANDES DE PLANTAS FORRAGEIRAS}

A baixa produção das pastagens durante o "inverno agrostológico" (maiosetembro) do Brasil Central tem sido apontada como um dos fatores que mais contribui para a reduzida produtividade dos rebanhos, sendo responsável por queda na produção leiteira, perda de peso dos animais de corte e pela redução na capacidade de suporte dos pastos, que, geralmente, é estabelecida tomando-se por base os doze meses do ano (Faria, 1971). Assim, a estacionalidade de produção de forragem, devido à filosofia do manejo adotado pela maioria dos pecuaristas, vem dificultando a economia da atividade pecuária, pois a taxa de lotação das pastagens é ajustada em função da produção mínima do "inverno" (Corsi, 1994) ou da área diferida para o pastejo durante o período seco (Rolim, 1994), não permitindo, portanto, que o potencial de produção animal, que o país apresenta, seja aproveitado.

Os fatores climáticos responsáveis pela estacionalidade de produção das plantas forrageiras variam de uma região para outra. As respostas a esses fatores são variáveis de acordo com as espécies (Rolim, 1994). As espécies tropicais apresentam taxa de fotossíntese líquida máxima à temperaturas por volta de $30-35^{0} \mathrm{C}$ (Cooper, 1970) e mínima por volta de $15^{0} \mathrm{C}$ (Cooper \& Tainton, 1968). As baixas temperaturas noturnas de inverno, que ocorrem nos trópicos e subtrópicos, são apontadas como os principais agentes causadores da estacionalidade de crescimento das plantas forrageiras tropicais (Cooper \& Tainton, 1968). A associação de baixas temperaturas e fotoperíodos curtos é 
o principal fator climático limitante do crescimento de espécies tropicais e subtropicais (Sweeney \& Hopkinson ${ }^{1}$, citados por Rolim, 1994).

Segundo Corsi \& Santos (1995), apesar do aparente conhecimento que técnicos e pecuaristas têm sobre P. maximum, na prática isso não ocorre, podendo ser demonstrado quando se espera produções elevadas durante o "inverno", justamente quando esta espécie apresenta seu pior desempenho devido à sua elevada estacionalidade de produção. Somente cerca de $10 \%$ da produção anual é obtida durante o "inverno". Quando explorado no "verão", esse capim pode contribuir para que a maior parte da propriedade seja utilizada para a produção de alimentos, para serem consumidos no “inverno".

Fica evidente, portanto, a íntima relação entre fatores ambientais e a ocorrência e distribuição das plantas forrageiras, mostrando a necessidade de se conhecer a disponibilidade destes fatores de crescimento e as características ecológicas e fenológicas das plantas a serem trabalhadas, para que se possa obter produtividade e longevidade dentro de uma filosofia de exploração racional de pastagens (Silva, 1995).

\subsubsection{1 Água}

A pluviosidade parece ser um dos fatores de maior importância na distribuição da tribo Paniceae, com as maiores concentrações dessas plantas ocorrendo em áreas com índices pluviométricos anuais acima de $760 \mathrm{~mm}$. Nas plantas do gênero Panicum, este valor fica mais próximo de $1.300 \mathrm{~mm}$ (McCosker \& Teitzel, 1975). Sob condições megatérmicas (temperaturas médias anuais iguais ou superiores a $29^{0} \mathrm{C}$ e de inverno acima de $15^{0} \mathrm{C}$ ), características das regiões tropicais e subtropicais de baixas latitudes, o fator temperatura perde importância e as condições hídricas assumem papel preponderante no controle das fases fenológicas das plantas (Silva, 1995).

${ }^{1}$ SWEENEY, F.C.; HOPKINSON, J.M. Vegetative growth of nineteen tropical and subtropical pasture grasses and legumes in relation to temperature. Tropical Grasslands, v. 9, p. 209-217, 1975. 
Segundo Corsi \& Nascimento Jr. (1994), até plantas que crescem em solos na capacidade de campo podem desenvolver déficit hídrico quando as condições ambientais favorecem elevados níveis de evapotranspiração. Nestas condições, Turner \& Begg ${ }^{2}$, citados por Corsi \& Nascimento Jr.,(1994), esclareceram que o nível de água no solo só tem a finalidade de estabelecer os limites de recuperação da planta durante o período noturno.

Muitos processos fisiológicos na planta forrageira, como expansão e alongamento de folhas, abertura e fechamento estomático e, consequentemente, fotossíntese, são, principalmente, regulados pela pressão de turgescência das células (Taiz \& Zeiger, 1998). Assim, Dias Filho (1986) determinou, em capim Tobiatã, correlação significativa entre expansão foliar e nível de umidade do solo. Essa gramínea, em condições normais de umidade, apresentou expansão foliar de $7 \mathrm{~cm} \mathrm{dia}^{-1}$, enquanto que, sob "déficit" hídrico moderado, esse valor foi reduzido em torno de $60 \%$. Trabalhos realizados por Turner $\& \mathrm{Begg}^{2}$, indicam que o crescimento em extensão, como por exemplo, expansão de folhas, é mais sensível ao "déficit" hídrico do que o fechamento dos estômatos. Desse modo, antes da ocorrência do fechamento estomático, o crescimento da planta já está prejudicado.

Após um período de "déficit" hídrico, quando as plantas reabsorverem água, a taxa de expansão foliar pode ser maior do que nas plantas que não sofreram estresse. Segundo Marshall (1987), isso pode refletir na utilização de carboidratos ou outros substratos acumulados na base das folhas durante o período de estresse, porém, é mais provável ser o resultado do crescimento simultâneo de um grande número de células também acumuladas nesse período, já que o processo de divisão celular também parece ser menos sensível ao estresse hídrico do que o de expansão celular.

${ }^{2}$ TURNER, N.C.; BEGG, J.E. Responses of pasture plants to water deficits. In: WILSON, J.E. (Ed.) Plant relations in pastures. Melbourne: Commonwealth Scientific and Industrial Research Organization, p. 50-66, 1978. 
Rodrigues \& Rodrigues (1987) relataram que o ecossistema de pastagens é basicamente regulado por três processos interagentes: assimilação e alocação de carbono, assimilação e alocação de nitrogênio e evapotranspiração. Com isso, além de afetar os processos fisiológicos e as características morfológicas, o estresse hídrico pode prejudicar o crescimento da pastagem, pela redução na absorção de nitrogênio. Em um trabalho de McNaughton et al. ${ }^{3}$, citados por Rodrigues \& Rodrigues (1987), avaliando a interação entre fluxos de carbono, nitrogênio e água na produção de pastagens, os autores observaram que, quando apenas nitrogênio foi adicionado ao sistema, ocorreu um pequeno aumento em produtividade. A adição de água dobrou a produção em vários anos de estudo. Porém, a adição conjunta de água e nitrogênio elevou a produção de massa seca em cerca de 5 a 8 vezes em relação ao tratamento controle, demonstrando, com isso, a forte interação existente entre a água e o nitrogênio, no aumento de produtividade da pastagem.

\subsubsection{Luz}

A radiação que atinge a superfície da crosta terrestre, denominada de radiação global, é composta de radiação solar direta e radiação difusa na atmosfera. A intensidade de radiação difusa depende da latitude, altitude, ângulo solar, nebulosidade e da turbidez da atmosfera. Grande parte da energia disponível para as plantas está na forma de radiação difusa, que, por ser multidirecional, atinge mais facilmente o interior e as partes inferiores do dossel. Segundo Bernardes \& Lima (2000), a radiação difusa aumenta em relação à radiação global com maiores latitudes, menores altitudes, maior nebulosidade, maior turbidez da atmosfera e menor elevação solar (mais radiação difusa nas primeiras e últimas horas do dia).

$\overline{{ }^{3} \text { McNAUGHTON, S.J.; COUGHENOUR, M.B.; WALLACE, L.L. Interactive processes }}$ in grassland ecosystems. In: ESTES, J.R. et al. (Ed.) Grasses and grasslandssystematics and ecology. Norman: University of Oklahoma Press, 1982. p. 167193. 
A radiação fotossinteticamente ativa (RFA) refere-se à energia radiante disponível para fotossíntese, geralmente definida pelos limites de 400 a $700 \mathrm{~nm}$ do espectro visível (Bernardes, 1987). Simulando os valores de RFA nas latitudes de 52, 22 e $5{ }^{0} \mathrm{~S}$, para o dia 16 de dezembro, Bernardes \& Lima (2000) verificaram que, em torno do meio do dia, nos trópicos, a RFA apresenta valores acima daqueles que saturam as folhas por radiação. Além disso, é nesse período do dia que as plantas encontram-se com o potencial de água nas folhas insuficiente para manter os estômatos abertos. Portanto, esse excesso de radiação não é aproveitado integralmente pelas plantas, mostrando que a máxima taxa de fotossíntese diária é observada na primeira parte da manhã, algumas horas antes do pico diário de irradiância, quando os estômatos encontram-se no seu ponto máximo de abertura.

O regime de radiação é o determinante básico do crescimento das plantas, através dos seus efeitos sobre a fotossíntese e outros processos fisiológicos, como a transpiração e a absorção de nutrientes (Bernardes, 1987). A absorção e utilização fotossintética da energia solar pela comunidade vegetal estão relacionadas com a quantidade de energia recebida pelas folhas de forma individual, e por toda a comunidade. Em um determinado instante, os elementos fotossinteticamente ativos dessa comunidade compreendem uma série de estruturas de diferentes idades, que estão sujeitas não somente aos efeitos do clima, mas também de outras restrições ambientais, como o autosombreamento, que aumenta com o desenvolvimento da pastagem (Rodrigues \& Rodrigues, 1987).

As produções de massa seca mais elevadas encontradas em plantas $\mathrm{C}_{4}$, quando comparadas às $\mathrm{C}_{3}$, têm sido atribuídas ao período de crescimento mais longo, decorrente de condições ambientais mais favoráveis nas regiões tropicais. Na verdade, o potencial de produção mais elevado apresentado pelas espécies $\mathrm{C}_{4}$ perenes, em baixas latitudes, é praticamente eliminado entre 40 e $50^{\circ}$ de latitude, sugerindo que a vantagem real da via metabólica $\mathrm{C}_{4}$ reside na melhor adaptação dessas plantas às condições de maior insolação e temperatura e, consequentemente, numa melhor eficiência no uso de água (Rodrigues \& Rodrigues, 1987). 
A radiação solar interfere, ainda, no crescimento das plantas através da variação estacional que se observa no comprimento do dia em diferentes latitudes. Em um grande número de espécies forrageiras, a mudança do estádio vegetativo de crescimento para o reprodutivo é induzida pela mudança no comprimento do dia (Humphreys, 1991). O fotoperíodo não só condiciona se uma planta irá florescer e produzir sementes em uma determinada região, mas também determina o comprimento do período vegetativo de crescimento, que é de grande importância para pastagens.

As maiores produções concentradas no período de primavera-verão, principalmente em dosséis não irrigados, devem-se a maior precipitação no período, por ser a água o fator limitante, enquanto, nos cultivos irrigados, a distribuição irregular na produção de forragem está associada à variação de temperatura e luminosidade durante o ano (Costa \& Monteiro, 1997). O aumento do fotoperíodo resulta em diminuição progressiva do nível de hormônios inibidores presentes na planta, que, aliada à elevação de temperatura, reiniciam ou aceleram o desenvolvimento das gemas. Essa fase está associada, de maneira geral, ao aumento do nível de giberilinas e de outras substâncias promotoras de crescimento.

Em um trabalho conduzido na Austrália (Burt, 1968) com capim Buffel (Cenchrus ciliaris L.), foi demonstrado que, em condições naturais, o aumento na radiação solar estimula a produção das diferentes partes da planta (número de folhas e perfilhos, biomassa de parte aérea, raízes e rizomas). Neste contexto, poder-se-ia esperar que o sombreamento reduzisse a produção de forragem, principalmente de folhas, já que nessas condições há um estiolamento das plantas, aumentando a produção de hastes (Hay \& Walker, 1989). De fato, em um experimento realizado com Cynodon dactylon cv. Coastal (Burton et al., 1959), constatou-se que na redução de disponibilidade de luz, houve diminuição da produção de massa seca de forragem, da produção de raízes e rizomas e do teor de carboidratos de reserva na planta.

Kephart et al. (1992), estudando respostas produtivas de gramíneas $\mathrm{C}_{3}$ e $\mathrm{C}_{4}$ a diferentes níveis de radiação, demonstraram o maior ponto de saturação lumínica para as tropicais. Os autores utilizaram níveis crescentes de radiação incidente e, observaram que a massa de folhas por perfilho foi relativamente constante sob todos os níveis de 
radiação para as espécies $\mathrm{C}_{3}$, enquanto que as $\mathrm{C}_{4}$ responderam positivamente aos incrementos em radiação.

\subsubsection{Temperatura}

Wang (1960) descreveu que as taxas de crescimento das plantas em função da temperatura são sigmóides e não lineares, tendo as temperaturas extremas apresentado efeitos negativos sobre a taxa de crescimento. $\mathrm{O}$ autor salientou ainda que, existe influência do fotoperíodo e deficiência hídrica nas respostas das plantas a variações na temperatura. Segundo Silva (1995), em regiões mesotérmicas (temperaturas médias anuais de $10-20{ }^{0} \mathrm{C}$ e de inverno entre $5-15{ }^{0} \mathrm{C}$ ), a temperatura exerce papel tão importante quanto a umidade na ocorrência e distribuição das plantas, sendo que nessas condições, desenvolvem-se aquelas que conseguem completar seus ciclos com temperaturas superiores a $0{ }^{0} \mathrm{C}$.

As variações diárias na taxa de expansão de folhas são correlacionadas com a média diária de temperatura do ar. Segundo Marshall (1987), as respostas produtivas à temperatura são reduzidas por "déficit" hídrico, porém, na ausência de seca, a temperatura média diária do ar pode ser utilizada para predizer produtividade, já que a taxa de expansão foliar seria o principal determinante de produtividade do dossel.

Os efeitos da temperatura mínima sobre o potencial produtivo do capim Pangola (Digitaria eriantha Steud.) foram avaliados por $\mathrm{McCloud}^{4}$, citado por Müller (2000). A redução de temperatura noturna de $30{ }^{0} \mathrm{C}$ para $20{ }^{0} \mathrm{C}$ e, posteriormente para $10{ }^{0} \mathrm{C}$, promoveu redução da produção de massa seca em 25 e 44,5\%, respectivamente. A manutenção da temperatura em $10{ }^{0} \mathrm{C}$ proporcionou produção relativa de $21 \%$ daquela obtida a $30{ }^{0} \mathrm{C}$. Cooper \& Tainton (1968) também descreveram uma drástica redução na taxa fotossintética e na expansão de folhas de plantas do gênero Panicum, quando submetidas à temperaturas inferiores a $15{ }^{\circ} \mathrm{C}$.

\footnotetext{
${ }^{4}$ McCLOUD, D.E. Temperature responses of some subtropical forage grasses. In: REUNION DEL GRUO DE TRABAJO DE LA FAO SOBRE O MEJORAMIENTO DE PASTOS Y FORRAJES EN LA AMERICA TROPICAL, 2., São Paulo, 1962. Informe. Roma: FAO, 1963. p. 11
} 


\subsubsection{DETERMINANTES MORFOLÓGICOS DA PRODUÇÃO PRIMÁRIA EM ESTANDES DE PLANTAS FORRAGEIRAS}

Estudos sobre a morfologia de plantas forrageiras evidenciam que a recuperação de uma pastagem após desfolha, por corte ou pastejo, é influenciada por suas características morfológicas, tais como a área foliar remanescente e o número de pontos de crescimento capazes de promover a rebrota (Ward \& Blaser, 1961; Gomide, 1973a; Jacques, 1973; Rodrigues \& Rodrigues, 1987). É consenso na literatura que o manejo da pastagem deve ser realizado tendo como um dos objetivos principais a obtenção de uma rebrota vigorosa após a utilização do pasto (Hodgson, 1990; Corsi \& Nascimento Jr., 1994). Com base na necessidade da planta em rebrotar com vigor após a desfolha, os métodos de pastejo devem procurar otimizar a interrelação entre índice de área foliar (IAF), interceptação luminosa (IL), acúmulo de carboidratos, e crescimento da pastagem. Essa interrelação é extremamente complexa e tem impacto sobre as taxas de fotossíntese foliar, que variam em função de IAF, IL, arquitetura e eficiência fotossintética.

Rhodes \& Mee (1980), estudando características de seleção para altas produções de massa seca em azevém (Lolium perenne L.), sugeriram a morfologia como um critério eficiente de seleção de plantas de alta produção, visto que a arquitetura do dossel afeta fortemente, através de diferentes graus de interceptação luminosa, a produção de massa seca.

Os parâmetros morfológicos são, basicamente, determinados geneticamente. No entanto, os fatores ambientais, não somente luz, temperatura, umidade, fertilidade do solo, mas também os efeitos de corte e/ou pastejo, são importantes modificadores desses parâmetros da arquitetura do dossel, sendo capazes de promover adaptações morfológicas nas plantas em função de estresses causados à comunidade (Kidd, 1966; Hyder, 1972; Matches, 1992). 


\subsubsection{1 Índice de área foliar (IAF)}

Segundo Gomide (1973a), o índice de área foliar (IAF; área de folhas/área de solo ocupado) é uma medida do potencial de desenvolvimento e de produção de forragem, que está diretamente relacionada com a eficiência de utilização da energia solar incidente, através do processo de fotossíntese.

Brown \& Blaser (1968) discutiram o conceito de IAF no desenvolvimento e manejo do pasto, como uma ferramenta capaz de facilitar o entendimento das relações entre as propriedades físicas e fisiológicas da comunidade vegetal. Esses autores demonstraram que a importância do conceito de IAF na taxa de crescimento do pasto está relacionada à IL. Em geral, elevações nos valores de IAF determinam aumentos nos valores de IL e, consequentemente, nas taxas fotossintéticas do dossel.

Rhodes (1973) observou que, gramíneas de hábito de crescimento ereto possuem um baixo coeficiente de extinção de luz (k) e um IAF ótimo mais elevado que gramíneas prostradas. O coeficiente de extinção é um parâmetro que combina características morfológicas da planta com as de arquitetura da comunidade vegetal (Hay \& Walker, 1989) e é definido pela equação:

$$
\mathrm{k}=-\left[\log _{\mathrm{e}}\left(\mathrm{I} / \mathrm{I}_{0}\right)\right] / \mathrm{IAF}
$$

onde $\mathrm{I}$ e $\mathrm{I}_{0}$ correspondem aos valores de irradiância abaixo e acima da folhagem, respectivamente. King et al. (1984), avaliando taxas fotossintéticas e balanço de carbono em pastos de azevém perene (Lolium perenne L.), observaram uma relação linear entre IAF e taxa de fotossíntese líquida do dossel.

Brougham (1958) postulou que a quantidade de massa seca remanescente após desfolha influencia diretamente a IL, resultando em variações no acúmulo de massa seca.

Aguiar (2000) relatou que rebrotas a partir de IAF zero ou próximo disso, é altamente dependente das reservas de carboidratos e, por isso, lenta. A partir da formação das primeiras folhas, a planta passa a não depender de suas reservas orgânicas e a produzir massa seca a partir da fotossíntese. 
Da mesma forma, Jones \& Carabaly ${ }^{5}$, citados por Rodrigues \& Rodrigues (1987), verificaram que o vigor de rebrota, tanto em espécies prostradas como em cespitosas, está correlacionado com a área foliar e quantidade de massa seca reidual após desfolha. Aqueles autores concluíram que no manejo de espécies cespitosas deve-se evitar desfolhas sucessivas e drásticas, objetivando manter a produtividade das rebrotas.

Parsons et al. (1983), avaliando alguns parâmetros fisiológicos em pastos de azevém perene, compararam dois níveis de IAF residual e observaram que no pastejo mais intenso, as folhas em crescimento foram mais eficientes fotossinteticamente, e que a emissão de folhas novas contribuiu em $77 \%$ na fotossíntese líquida. Entretanto, apesar da alta eficiência fotossintética por unidade de folha no pastejo mais intenso, a fotossíntese do dossel foi substancialmente menor naquele sistema de pastejo.

\subsubsection{2 Ângulos foliares}

O arranjo espacial da área foliar no dossel de pastagens apresenta um efeito marcante na quantidade de luz interceptada e, consequentemente, no potencial fotossintético da comunidade (Marshall, 1987). O ângulo de inserção foliar é um parâmetro importante pois é um dos fatores que regula o grau de penetração da radiação solar no dossel. Sheehy \& Cooper (1973) verificaram que os valores de taxas de crescimento variaram com a arquitetura do dossel e com o valor do coeficiente de extinção luminosa. Comunidades com arquitetura mais vertical e, consequentemente, menores valores de coeficiente de extinção, apresentam, de forma geral, maiores taxas de crescimento do que aqueles dosséis de folhas mais planófilas.

Segundo Gomide (1973b), as folhas de gramíneas diferem das de leguminosas pelo ângulo agudo que formam com a haste; consequentemente, o IAF crítico é, geralmente, maior para gramíneas, resultando em melhor distribuição e maior eficiência no aproveitamento da luz solar.

${ }^{5}$ JONES, C.A.; CARABALY, A. Some characteristics of the regrowth of 12 tropical grasses. Tropical Agriculture, v. 58, p. 37-44, 1981. 
No caso das espécies forrageiras componentes de pastagens, as diferenças na forma de propagação e hábitos de crescimento podem permitir diferentes aproveitamentos da energia solar. Em muitas leguminosas, e principalmente no trevo branco (Trifolium repens L.), a radiação solar é mal aproveitada devido ao ângulo de inserção da folha com a haste ser relativamente grande (i.e., folhas predominantemente planas) e a distribuição das folhas dentro do dossel vegetativo, que não permite alto aproveitamento da luz solar. Existe uma grande dificuldade de penetração da luz no perfil e a luz refletida não tem a oportunidade de ser reaproveitada por difusão dentro do dossel, como ocorre numa comunidade com predominância de gramíneas, onde as folhas são mais eretas.

Segundo Bernardes (1987), as diferenças de interceptação de luz e taxa fotossintética relacionadas com ângulo foliar ocorrem principalmente para luz direta, e são também dependentes da elevação solar. Assim, para ângulo foliar de $0^{\circ}$ (folhas planófilas), as variações na produção de massa seca em função do IAF ou da hora do dia são pequenas. Para um ângulo foliar de $80^{\circ}$, a produção é maior quanto maior for o IAF, ocorrendo diferenças nas horas de maior disponibilidade de radiação direta.

Comprovando a teoria de que folhas eretas favorecem a distribuição de luz no perfil do dossel, Warren-Wilson (1961) criou uma situação hipotética e demonstrou que após provocar uma inclinação de $81^{\circ}$ na folha, esta aumentou sua superfície iluminada em aproximadamente seis vezes, além de sua assimilação líquida total ser duas vezes maior do que quando a folha estava disposta horizontalmente, demonstrando que folhas mais eretas utilizam a luz mais eficientemente e que, em uma mesma área de projeção vertical, podem apresentar uma maior assimilação líquida do que folhas horizontais.

Segundo Marshall (1987), folhas dispostas horizontalmente absorvem mais luz sob mais baixos valores de IAF do que folhas eretas. Como consequiência disso, comunidades com predominância de folhas planas tendem a ser mais produtivas a baixos níveis de radiação, ou ainda, sob alta frequência de corte ou pastejo e, inversamente, comunidades com folhas mais eretas são mais produtivas sob altos níveis de radiação ou sob menores freqüências de corte ou pastejo. 


\subsubsection{Interceptação luminosa}

Segundo Marshall (1987), a produção de massa seca de um dossel intensivamente manejado, com suprimentos adequados de água e nutrientes, é determinada pela eficiência com a qual as folhas interceptam a luz e a utilizam na assimilação de carbono. Observações em várias culturas indicam que a taxa de acúmulo de massa seca e a produção total de fitomassa, são uma função linear da quantidade de radiação interceptada e utilizada pelo dossel.

Vários são os aspectos morfofisiológicos que estão envolvidos na interceptação da luz pelos vegetais. Uns correspondem a aspectos relacionados com a organização espacial das folhas, pela densidade de cobertura foliar, distribuição horizontal e vertical entre as folhas e pelo ângulo foliar. Outros, correspondem àqueles relacionados com aspectos funcionais que dependem de fatores da planta e do ambiente como: idade, tipo e tamanho das folhas, saturação luminosa, flutuações na intensidade e na qualidade da luz (Bernardes, 1987). A quantidade de energia radiante que chega ao dossel é atenuada à medida que ela vai penetrando nas camadas inferiores do perfil. Segundo Humphreys (1991), o arranjo geométrico do dossel influencia o ambiente luminoso e as taxas fotossintéticas das superfícies clorofiladas abaixo das folhas e hastes superiores.

A utilização ótima da luz solar incidente foi proposta por Warren-Wilson (1961) como sendo aquela que ocorre quando a folhagem de um dossel fechado recebe luz de intensidade uniforme e relativamente baixa, e com as folhas basais permanecendo no ponto de saturação luminosa. Essa situação hipotética poderia existir, ao menos teoricamente, através de um arranjo espacial adequado de uma área foliar apropriada (Silva \& Pedreira, 1997).

Silva \& Pedreira (1997) relataram que o desenvolvimento do conceito de IAF por Watson (1947), possibilitou a racionalização e um melhor entendimento das relações entre a interceptação luminosa e o acúmulo de massa seca das plantas. Em um valor de IAF chamado de ótimo, a interceptação de aproximadamente toda a luz incidente, com um mínimo de auto-sombreamento, proporcionaria o máximo valor de taxa de acúmulo de forragem (acúmulo de massa seca por unidade de área, por unidade de tempo) 
(Rhodes, 1973). O valor de IAF que proporciona 95\% de IL e no qual o valor da taxa de acúmulo de forragem está próxima da máxima, é definido como IAF crítico. Abaixo do IAF ótimo as taxas de acúmulo são dependentes do IAF e são mais reduzidas quando a IL é incompleta, enquanto que acima do IAF ótimo, a redução nas taxas de acúmulo é causada pelo aumento das perdas respiratórias, conseqüência do sombreamento excessivo, que resulta em um balanço negativo de carbono (Hay \& Walker, 1989).

\subsubsection{DETERMINANTES FISIOLÓgICOS DA PRODUÇÃo PRIMÁRIA EM ESTANDES DE PLANTAS FORRAGEIRAS}

\subsubsection{Fotossíntese de Folhas Individuais}

A síntese de tecido vegetal tem como base a energia de carboidratos simples produzidos via fotossíntese, que é desencadeada quando os cloroplastos dos tecidos das folhas verdes são expostos à luz. A conversão de energia luminosa em energia química, é, no entanto, um processo ineficiente, onde apenas 2 a $5 \%$ da energia luminosa que chega a superfície do dossel pode efetivamente ser utilizada no crescimento do dossel (Bernardes, 1987).

A importância relativa das taxas de fotossíntese de folhas individuais na formação da produção tem sido objeto de controvérsia ao longo dos anos (Silva \& Pedreira, 1997). Em muitos casos, a literatura reporta um suposto paradoxo baseado na inexistência de uma associação clara entre as taxas de assimilação de $\mathrm{CO}_{2}$ por unidade de área foliar e a produção de matéria seca. Segundo Zelitch (1982), o que ocorre é que não se deve esperar que medidas de fotossíntese tomadas instantaneamente por unidade de área foliar, representem a assimilação líquida de $\mathrm{CO}_{2}$ de toda a planta durante toda a estação de crescimento.

As folhas individuais apresentam grande variação em sua capacidade fotossintética, que é determinada por vários fatores como a quantidade de radiação solar incidente, temperatura, suprimento de água e, principalmente, o seu estádio de desenvolvimento. Folhas completamente expandidas realizam fotossíntese com 
intensidade máxima e os assimilados por elas formados servem não apenas para sua própria manutenção como para atender às necessidades do meristema apical, do sistema radicular e das folhas em formação. Folhas que ainda não atingiram a expansão completa, não translocam assimilados para outras partes do perfilho, usando-os para o seu próprio desenvolvimento (Zelitch, 1982). Com isso, a idade das folhas remanescentes após a desfolhação, e sua relação com a eficiência de absorção de $\mathrm{CO}_{2}$ na taxa de acúmulo de forragem, assume fundamental importância, como demonstrado por Brown et al. (1966). Avaliando três espécies forrageiras, alfafa (Medicago sativa L.), trevo branco (Trifolium repens L.) e Phalaris arundinacea (L.), esses autores observaram que plantas com predominância de folhagem remanescente apical cresceram mais rapidamente que plantas com folhagem predominantemente basal, ou seja, com folhas mais velhas. Demonstraram, ainda, que, plantas de trevo branco com folhagem com idade de 1 a 2 semanas absorveram mais $\mathrm{CO}_{2}$ e produziram mais matéria seca do que plantas com folhas de 3 a 4 semanas de idade. Com isso, os autores concluíram que a idade da folha e, consequentemente, sua eficiência, é um fator de extrema importância quando a proposta de manejo inclui a manipulação do IAF visando aumentos de produtividade.

O nível de eficiência fotossintética das folhas novas depende do ambiente em que elas se desenvolvem. Se a espécie forrageira tem hábito de crescimento prostrado, o desenvolvimento de folhas novas ocorrerá em um ambiente de baixa intensidade luminosa, o mesmo ocorrendo para as folhas de perfilhos que iniciam o crescimento na base de touceiras de espécies com hábito de crescimento cespitoso (Corsi \& Nascimento Júnior, 1994). Assim, folhas que se desenvolvem em ambiente de baixa intensidade luminosa apresentam menor eficiência fotossintética que aquelas que se desenvolvem sem sofrer competição por luz.

A temperatura foliar exerce um papel fundamental em todos os processos fisiológicos e bioquímicos das plantas forrageiras, sendo a fotossíntese um dos mais responsivos a este componente ambiental. Na literatura é reportado que extremos de temperaturas foliares são prejudiciais para a realização do processo fotossintético (Cooper \& Tainton, 1968; Powles, 1984; Oberhuber and Edwards, 1993). Para espécies 
forrageiras tropicais, essa amplitude estaria por volta de $35{ }^{0} \mathrm{C}$ (nível ótimo) e $15{ }^{0} \mathrm{C}$ (temperatura base, abaixo da qual essas plantas cessam seu crescimento). De maneira geral, a fotossíntese é mais sensível à temperatura e apresenta um valor mais elevado de temperatura ótima em espécies $C_{4}$ quando comparadas às $C_{3}$ (Kephart et al., 1992).

Diferentes componentes do processo fotossintético são afetados quando as folhas são expostas a baixas temperaturas, tais como a inibição da biossíntese de clorofilas (Hodgins \& Van Huystee, 1986), dano na cadeia transportadora de elétrons ou em enzimas solúveis do estroma da fase bioquímica da fotossíntese (Taiz \& Zeiger, 1998).

Alterações fisiológicas em folhas de milho submetidas a baixas temperaturas ocorrem, segundo Walker ${ }^{6}$, citado por Müller (2000), devido à mudança na permeabilidade da membrana celular e ao aumento da viscosidade da seiva das células da região meristemática da raiz. Em consequência desses processos, há redução na absorção de água e nutrientes, diminuindo, com isso, a translocação e a velocidade das reações bioquímicas do vegetal. Mello et al. (2001a) avaliaram a resposta fotossintética do capim Tanzânia sob quatro níveis de temperatura foliar $\left(25,30,35\right.$ e $\left.40^{\circ} \mathrm{C}\right)$ e, observaram uma taxa máxima de fotossíntese líquida $\left(34,57 \mu \mathrm{mol}\right.$ de $\left.\mathrm{CO}_{2} \mathrm{~m}^{-2} \mathrm{~s}^{-1}\right)$ na temperatura de $35^{\circ} \mathrm{C}$. Sob $40^{\circ} \mathrm{C}$ de temperatura, as respostas foram mais variáveis e houve redução na taxa máxima de fotossíntese líquida $\left(27,53 \mu \mathrm{mol}\right.$ de $\left.\mathrm{CO}_{2} \mathrm{~m}^{-2} \mathrm{~s}^{-1}\right)$, devido, provavelmente, ao estresse térmico causado por essa temperatura nas folhas da gramínea. À medida que temperatura se eleva a níveis acima do ótimo, as taxas fotossintéticas começam a decrescer, inicialmente, de maneira gradual e reversível e, posteriormente, de maneira irreversível, quando a temperatura atinge valores críticos (Powles, 1984).

Apesar de $90 \%$ do peso seco das plantas ser oriundo da assimilação de $\mathrm{CO}_{2}$ via fotossíntese (Zelitch, 1982), não parece haver limitações à produção devido às taxas fotossintéticas. O que ocorre mais provavelmente é que outras variáveis fisiológicas e de ambiente, tais como déficit hídrico e relações fonte-dreno, impõem limites à produção e à produtividade.

${ }^{6}$ WALKER, J.M. One-degree increments in soil temperatures affect maize seedling behavior. Procedings of Society Soil Science and Animal, v. 33, p. 729-736, 1969. 


\subsubsection{Fotossíntese de dossel}

A taxa fotossintética pode ser expressa como o produto entre a quantidade de luz interceptada e a eficiência com que os tecidos foliares a utilizam. Verhagen et al. (1963) e Pearce et al. (1965) concordaram que a produção de massa seca depende desses dois fatores. Além disso, os autores citaram que a forma, o arranjo, o tamanho e a quantidade de folhas afetam sobremaneira a interceptação e a reflexão da luz incidente no relvado. Pearce et al. (1965) indicaram ainda que, a quantidade de $\mathrm{CO}_{2}$ absorvido pelas folhas pode ser utilizada como estimativa do potencial de produção da forrageira.

O aumento da fitomassa em uma área cultivada depende do desenvolvimento de sua área foliar. A distribuição do IAF pelo perfil do dossel em plantas com diferentes morfologias pode explicar, parcialmente, eventuais diferenças observadas em produção, embora seja comprovada a existência de interações entre a morfologia e o regime de desfolha (Rhodes, 1971). Quando os intervalos entre desfolhas são curtos, plantas com maior proporção do IAF na parte inferior do dossel apresentam maior IAF residual, o que assegura uma rápida rebrota inicial após desfolhação, através de uma maior interceptação luminosa. Entretanto, se o período de rebrota é longo, as plantas de crescimento mais alto e ereto, com maiores proporções do IAF nas regiões intermediária e superior do dossel, têm tempo suficiente para acumular um grande IAF e utilizam melhor a radiação incidente, sendo, portanto, mais produtivas (Fagundes, 1999).

A distribuição da folhagem nas camadas do perfil do dossel afeta de forma marcante a interceptação e a distribuição de luz (Warren Wilson, 1961) e, nesse sentido, é importante conhecer como o IAF está arranjado verticalmente no dossel. Essa distribuição tem implicação não só do ponto de vista morfológico, afetando a proporção da forragem que é removida pelo corte ou pastejo a uma determinada altura, mas também é importante fisiologicamente nos processos de fotossíntese e competição por luz, especialmente em pastagens consorciadas, pois as folhas não recebem radiação de maneira uniforme, tendo as folhas apicais tendência de receber mais luz que as folhas basais. Entretanto, quando as folhas do topo do dossel são verticais, parte da radiação não é interceptada por essas folhas, tornando-se disponíveis para as folhas da base que, a 
partir daí, passam a contribuir com a capacidade fotossintética do dossel (Hay \& Walker, 1989).

Se uma quantidade considerável das folhas está confinada em uma camada estreita do dossel (alta densidade), há grande superposição, resultando em autosombreamento, principalmente se as folhas são grandes. Essa mesma quantidade de folhas distribuída em um horizonte maior do dossel, resulta em melhor distribuição e menor competição pela luz e, consequentemente, em taxas de crescimento mais altas (Warren Wilson, 1961).

\subsubsection{Partição de carbono}

Os compostos intermediários oriundos da fixação biológica do $\mathrm{CO}_{2}$ atmosférico e transformados em carboidratos (fotossíntese) são utilizados como fonte de energia para a síntese de tecidos, e translocados às diversas partes da planta (Donald, 1962; Zelitch, 1982). Em plantas $\mathrm{C}_{3}$, menos de $70 \%$ do potencial de fixação de $\mathrm{CO}_{2}$ é atingido devido à competição do $\mathrm{O}_{2}$ pelos sítios enzimáticos e à fotorrespiração. Do total de carboidratos assimilados, cerca de $50 \%$ é utilizado na respiração e o restante é distribuído entre os diferentes órgãos para a síntese de tecidos (Gifford et al., 1984). Os carboidratos produzidos durante a fotossíntese são utilizados para síntese de conteúdo celular e de tecido estrutural embora mais de $50 \%$ da energia seja utilizada para suportar o crescimento de novos tecidos nas folhas, hastes e raízes (Donald, 1962). Essa demanda energética resulta em perdas de $\mathrm{CO}_{2}$ para atmosfera pela respiração. Além disso, a senescência e decomposição de folhas velhas também compromete parte dessa energia sendo importante fonte de perdas. $\mathrm{O}$ resultado do balanço desses efeitos em uma comunidade de plantas determina a taxa de acúmulo líquido de carbono, obtida pela diferença entre os ganhos com o processo fotossintético e as perdas respiratórias, que crescem com o aumento do IAF (Hodgson, 1990).

Segundo Lemaire \& Chapman (1996), quando o aporte de fotoassimilados é suficientemente grande para suplementar as necessidades dos tecidos meristemáticos, o crescimento (principalmente de folhas) pode atingir o potencial determinado pelas 
condições de ambiente. $\mathrm{O}$ excesso de assimilados pode ser armazenado em órgãos de reserva para que sejam utilizados pelas plantas quando necessário.

O estudo da partição de assimilados na planta forrageira permite descrever o destino do carbono na planta e estabelecer os princípios fisiológicos que regem a produtividade dos pastos, fornecendo bases para o desenvolvimento de novas técnicas de manejo e de novos cultivares (Santos \& Corsi, 19997). O transporte de carboidratos é realizado sempre no sentido "da fonte para o dreno". Todos os órgãos de uma planta, em algum estádio de desenvolvimento, funcionam como dreno e, apenas alguns órgãos (e.g., folhas) passam de dreno para fonte (Taiz \& Zeiger, 1998).

A partição dos carboidratos depende de uma série de fatores fisiológicos, genéticos, e do ambiente, que, em alguns casos, podem ser manipulados de modo a aumentar a produtividade da pastagem. O estádio de desenvolvimento das plantas também pode determinar o padrão de distribuição dos carboidratos. Em pastos de azevém já estabelecidos e em estádio reprodutivo, Parsons \& Robson (1981) verificaram redução acentuada no teor de carboidratos alocado para o sistema radicular, coincidindo com o início do alongamento das hastes. Em áreas recém implantadas, onde o capim não sofreu vernalização e, consequentemente, não passou para o estádio reprodutivo, essa alteração na partição de carboidratos não foi observada.

No caso das pastagens, as plantas de maior interesse são aquelas que apresentam mecanismos de tolerância ao pastejo, caso em que os processos fisiológicos envolvidos dependem, em grande parte, da partição de carboidratos na planta (Santos \& Corsi, 1999). Comparando duas variedades de Panicum coloratum L., Dyer et al. (1991) observaram que a variedade mais adaptada ao pastejo produziu e armazenou mais carboidratos nas folhas, armazenou menos carboidratos nas hastes, apresentou maior atividade no floema e enviou mais carboidratos para as raízes (o principal órgão de reserva).

${ }^{7}$ SANTOS, P.M.; CORSI, M. (USP/ESALQ. Departamento de Produção Animal, Piracicaba). Partição de carboidratos na planta forrageira. Palestra proferida na disciplina "Seminários em Ciência Animal e Pastagens", 1999. 
O estudo da partição de nutrientes na planta forrageira também é importante para tomadas de decisão de manejo da pastagem. Fatores como a transição das folhas de dreno para fonte, padrão de distribuição dos carboidratos das fontes para os drenos, localização dos órgãos de reserva preferenciais, velocidade de translocação dos carboidratos e, consequentemente, da produção de tecidos e da formação de reservas, devem ser considerados na determinação da freqüência, intensidade e época de pastejo (Santos \& Corsi, 19997 ).

\subsection{ALTURA DO DOSSEL E SEUS EFEITOS SOBRE A PRODUÇÃO DA PASTAGEM}

Segundo Loomis \& Williams (1969), o estabelecimento de relações entre a morfologia ou arquitetura do dossel e o acúmulo de forragem pela planta apresenta uma série de dificuldades. Processos fisiológicos tais como translocação, respiração e o controle hormonal da partição de fotoassimilados atuam na determinação da correlação entre a produtividade primária e a produção de massa seca. Aqueles autores concluíram que a arquitetura do dossel afeta tanto a distribuição de luz dentro da população de plantas como a circulação de ar, que por sua vez afeta os processos de transferência de $\mathrm{CO}_{2}$ e evapotranspiração. Portanto, a arquitetura do dossel vegetativo afeta a IL pelas plantas e Haynes (1980) sugeriu que, provavelmente, a característica mais importante que determina a habilidade do dossel de competir por luz é a altura. Pequenas diferenças em altura do pasto podem gerar grandes efeitos na competição por luz, pois mesmo pequenas diferenças são suficientes para uma folha sobrepor-se à outra.

${ }^{7}$ SANTOS, P.M.; CORSI, M. (USP/ESALQ. Departamento de Produção Animal, Piracicaba). Partição de carboidratos na planta forrageira. Palestra proferida na disciplina "Seminários em Ciência Animal e Pastagens", 1999. 
Dentre as características do dossel vegetativo, Hodgson (1990) citou que as que mais afetam a produção de forragem e do animal e, consequentemente, as mais importantes para o manejo, são a altura do pasto, a massa e densidade de forragem e a quantidade de folhas. Maxwell \& Treacher (1987) mencionaram que a altura do dossel oferece a melhor ferramenta para o manejo da pastagem, objetivando o controle da produção de matéria seca e desempenho animal dentro do sistema. Esta característica afeta o crescimento e a senescência das plantas e, consequentemente, a produção líquida do pasto, além de afetar de maneira marcante o consumo e desempenho dos animais. Hodgson (1990) citou que há evidências que medidas de altura fornecem a melhor indicação da produção de forragem e desempenho do animal em circunstâncias particulares, e padrões mais consistentes de respostas sob diferentes condições. Em azevém perene, observa-se resposta mais consistente do consumo dos animais em relação à variações na altura do dossel do que na massa de forragem (Hodgson, 1990) e, segundo o autor, sendo a altura mais fácil de se mensurar, constitui-se em um parâmetro satisfatório de avaliação da pastagem.

Apesar da complexidade das interações entre os processos de crescimento, senescência e utilização da forragem, Maxwell \& Treacher (1987) relataram que, em sistemas de produção utilizando lotação contínua, em pastagens de plantas de clima temperado, a altura do pasto como um único critério, é capaz de fornecer a ligação entre o crescimento e utilização por área do pasto, estrutura do dossel, produtividade, consumo e desempenho do animal em pastejo.

\subsection{IRRIGAÇÃO EM PASTAGENS}

Um dos principais problemas enfrentados pelo setor produtivo é a estacionalidade da produção de forragem das espécies comumente utilizadas em sistemas de produção animal em pastagem (Müller, 2000), principalmente nas latitudes do Centro Sul do Brasil. Em graus variados, as baixas temperaturas, os baixos níveis de radiação solar e a reduzida disponibilidade hídrica no "inverno agrostológico" (abrilsetembro) têm sido apontados como os fatores limitantes à produção dos pastos. 
Alguns trabalhos (Alvim et al., 1986; Botrel et al., 1991) indicam, todavia, que nas latitudes tropicais, a água pode ser o principal fator limitante, o que tem estimulado um direcionamento de esforços da pesquisa para o potencial da irrigação como técnica capaz de atenuar ou minimizar o problema de escassez de forragem na época menos favorável do ano. A confirmação dessa hipótese poderá ter um importante impacto técnico e econômico sobre a viabilidade da "pecuária irrigada" em muitas áreas do Brasil Central. A irrigação, associada ao manejo adequado do pasto e à utilização de fertilizantes, explorando o potencial produtivo das espécies forrageiras tropicais, podem provocar aumento significativo da produtividade animal, diluindo os custos fixos do sistema de produção (Rolim, 1994).

A literatura concernente ao desempenho agronômico e econômico de pastagens irrigadas, ainda é bastante restrita e, segundo Müller (2000), o uso de irrigação em pastagens na região do Cerrado, por exemplo, é uma realidade fundamentada em experiências empíricas de produtores e que, ainda não encontra alicerces na pesquisa acadêmica. Apesar do crescente aumento na utilização da irrigação como forma de aumentar a produção dos pastos e, em função da elevação da capacidade de suporte da pastagem, da produtividade animal, Martins et al. (2000) destacaram que a resposta na capacidade produtiva das pastagens, em função da irrigação, está diretamente relacionada aos fatores climáticos, especialmente temperatura e fotoperíodo. Assim, a resposta das gramíneas tropicais irá variar em função da região e da espécie forrageira, o que pode ser visto na avaliação da produção de gramíneas de climas tropical e temperado realizada por Alvim et al. (1986). Guelfi Filho (1976), um dos pioneiros na pesquisa com irrigação em pastagens tropicais, verificou acréscimo de $48 \%$ na produção de massa seca de capim Colonião, quando irrigado no inverno, entretanto, não apresentando diferença na distribuição da produção de forragem, quando comparou com a testemunha no período de inverno. O autor relacionou estes resultados com as baixas temperaturas ocorridas na estação. Da mesma maneira Botrel et al. (1991) avaliaram o efeito da irrigação na produção de matéria seca de cultivares de capim Elefante e, observaram que, apesar da irrigação ter tido efeito positivo na produção de forragem, 
não alterou substancialmente a estacionalidade de produção desta forrageira, indicando o forte efeito da temperatura e fotoperíodo na estacionalidade de produção.

Deve-se buscar o aprimoramento do manejo de pastagens tropicais, objetivandose a exploração do potencial produtivo dessas plantas (Corsi \& Santos, 1995) e, com isso, a redução nos custos dos sistemas de produção. Para tal, é necessário o profundo conhecimento dos atributos relacionados às plantas e ao ecossistema em que elas estão inseridas. Esse conhecimento tem como princípio básico, o entendimento das propriedades morfológicas e fisiológicas que regem a produção de massa seca, e como a comunidade de plantas responde ao manejo adotado (Silva \& Pedreira, 1997). A obtenção de informações sobre as respostas das plantas ao manejo adotado, indica ao produtor como utilizar os fatores de manejo (adubação, irrigação, pressão de pastejo) de forma adequada, permitindo alta produtividade e, consequentemente, rentabilidade do sistema, sem o comprometimento da perenidade dos pastos. 


\section{MATERIAL E MÉTODOS}

$\mathrm{O}$ experimento foi conduzido na Fazenda Areão, pertencente à Escola Superior de Agricultura "Luiz de Queiroz" (USP/ ESALQ), em Piracicaba-SP ( $22^{0} 42^{\prime} 30^{\prime}$ ' S ; $47^{0}$ 38’30" W; 576 m), no período de 05/11/99 a 11/09/00, em uma área de 4,8 ha de pastagem de capim Tanzânia (Panicum maximum Jacq. cv. Tanzânia), irrigada por um sistema de pivô central. O clima, segundo a classificação de Köppen, é do tipo CwaTropical úmido (com chuvas de verão e três meses mais secos: junho, julho e agosto). Os valores de temperatura, precipitação e fotoperíodo observados na área, durante o período experimental, encontram-se na Tabela 2.

O solo da área é classificado como Podzólico Vermelho-Escuro de textura franco - argilosa, e teve suas características químicas avaliadas (Tabela 1), em outubro de 1999.

Tabela 1. Resultado da análise do solo realizada em outubro de 1999.

\begin{tabular}{|c|c|c|c|c|c|c|c|c|c|c|c|}
\hline \multirow[t]{2}{*}{$\mathrm{pH}$} & MO & $\mathrm{P}$ & $\mathrm{S}-\mathrm{SO}_{4}$ & $\mathrm{~K}$ & $\mathrm{Ca}$ & $\mathrm{Mg}$ & $\overline{\mathrm{Al}}$ & $\mathrm{H}+\mathrm{Al}$ & SB & $\mathrm{T}$ & $\bar{V}$ \\
\hline & $\mathrm{g} \mathrm{dm}^{-3}$ & \multicolumn{2}{|c|}{---mg dm ${ }^{-3}---$} & \multicolumn{7}{|c|}{ 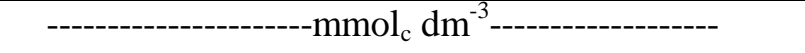 } & $\%$ \\
\hline 4,8 & 24 & 17 & 11 & 3,9 & 44 & 16 & 1 & 38 & 63,9 & 101,9 & 63 \\
\hline
\end{tabular}


Tabela 2. Dados climatológicos observados na Fazenda Areão - ESALQ/USP, no período de novembro de 1999 a setembro de 2000, Piracicaba-SP.

\begin{tabular}{lccccc}
\hline Mês/Ano & $\begin{array}{c}\mathrm{T}^{\mathrm{o}} \text { média } \\
\left({ }^{\circ} \mathrm{C}\right)\end{array}$ & $\begin{array}{c}\mathrm{T}^{\mathrm{o}} \text { máxima } \\
\left({ }^{\circ} \mathrm{C}\right)\end{array}$ & $\begin{array}{c}\mathrm{T}^{\mathrm{o}} \text { mínima } \\
\left({ }^{\circ} \mathrm{C}\right)\end{array}$ & $\begin{array}{c}\text { Precipitação } \\
(\mathrm{mm})\end{array}$ & $\begin{array}{c}\text { Fotoperíodo } \\
(\mathrm{h})\end{array}$ \\
\hline Novembro/99 & 21,6 & 28,9 & 15,4 & 51,6 & 13,1 \\
Dezembro/99 & 23,7 & 30,2 & 18,8 & 261,5 & 13,3 \\
Janeiro/00 & 23,4 & 29,7 & 18,9 & 224,1 & 13,2 \\
Fevereiro/00 & 23,5 & 29,6 & 19,4 & 117,1 & 12,8 \\
Março/00 & 22,8 & 29,1 & 18,6 & 166,5 & 12,1 \\
Abril/00 & 21,5 & 28,8 & 15,1 & 1,1 & 11,4 \\
Maio/00 & 18,4 & 26,1 & 11,9 & 4,8 & 10,9 \\
Junho/00 & 18,5 & 26,7 & 11,3 & 5,2 & 10,6 \\
Julho/00 & 16,0 & 24,1 & 9,1 & 61,0 & 10,8 \\
Agosto/00 & 19,0 & 27,1 & 12,1 & 25,0 & 11,3 \\
Setembro/00 & 20,3 & 26,8 & 15,1 & 88,9 & 11,7 \\
\hline
\end{tabular}

Fonte: Base de dados da estação metereológica automatizada, Área de física e metereologia - DCE - ESALQ - USP (2002)

O solo foi preparado entre janeiro e março de 1999. Antes da semeadura, o solo recebeu correções (calagem, fosfatagem e potassagem) para se atingirem valores próximos de: saturação por bases de $80 \%$; P de $25 \mathrm{mg} \mathrm{dm}^{-3}$ e $\mathrm{K}$ de $5 \%$ da CTC.

A semeadura foi feita em linhas nos dias 17 e 18 de março de 1999, utilizando-se $4 \mathrm{~kg} \mathrm{ha}^{-1}$ de sementes puras viáveis.

Os tratamentos foram três intensidades de pastejo, aplicados como quantidades de massa seca verde residual pós-pastejo $(\mathrm{T} 1=1.000$; T2=2.500 e T3=4.000 kg MSV ha ${ }^{1}$ ). O delineamento experimental utilizado foi o de blocos completos casualizados com quatro repetições. O método de pastejo utilizado foi lotação rotacionada, com ciclo de pastejo de 36 dias, sendo 3 e 33 dias de ocupação e descanso, respectivamente. As taxas de lotação para cada tratamento e ciclo de pastejo foram definidas em função da massa de forragem pré-pastejo, e o nível de massa seca residual definida pelos tratamentos. 
A área experimental de 4,8 ha foi dividida em doze parcelas de 0,4 ha, sendo que cada uma dessas foi subdividida em três piquetes iguais $(0,133 \mathrm{ha})$, a fim de permitir o ciclo de pastejo definido. Após cada pastejo, os piquetes receberam adubações correspondentes a $80 \mathrm{~kg} \mathrm{~N} \mathrm{ha}^{-1}$ e $80 \mathrm{~kg} \mathrm{~K}_{2} \mathrm{O} \mathrm{ha}^{-1}$.

Todos os piquetes eram irrigados por um pivô central. Após o estabelecimento, as irrigações passaram a ser controladas utilizando-se tensiômetros. Foram instalados 10 baterias de 6 tensiômetros, nas profundidades de 0,10;0,20;0,40;0,60;0,80 e 1,00 m. As leituras foram realizadas diariamente, até as 8 horas da manhã e, quando os tensiômetros instalados a 0,20 m indicavam valores médios na faixa de 0,3 a 0,4 bar de tensão de água no solo, promovia-se a irrigação.

Foram coletados dados de oito ciclos de pastejo (rebrotas de 33 dias), tendo início no pós-pastejo do ciclo $1(05 / 11 / 99)$ e término no pré-pastejo do ciclo 8 $(11 / 09 / 00)$.

Para todas as respostas, foram realizadas avaliações em quatro dias do período de rebrota $\left(1^{\circ}, 11^{\circ}, 22^{\circ}\right.$ e $33^{\circ}$ dias após a saída dos animais), com o intuito de traçar curvas de variação ao longo de cada rebrota (ciclo de pastejo) e também ao longo das estações do ano. Todas as medições ocorreram em piquetes escolhidos, de modo a representar a condição média de cada tratamento durante a estação de pastejo.

A altura média do dossel foi calculada como a média de 50 medições pontuais por piquete, para cada dia de amostragem. Essas leituras de altura eram realizadas na inflexão da folha mais alta da touceira, com o auxílio de uma trena.

As medições de índice de área foliar (IAF), interceptação luminosa (IL) e ângulos foliares médios (a partir do eixo horizontal) foram realizadas também em 50 pontos representativos da condição média da pastagem em cada piquete. Para essas avaliações, utilizou-se um analisador de dossel LI-COR modelo LAI 2000 (LI-COR, Lincoln, Nebraska, EUA), que permite amostragens rápidas e não destrutivas (Welles \& Norman, 1991). O aparelho é constituído de uma unidade de controle e de um sensor em formato de uma barra articulada. O sensor consiste de um conjunto de lentes tipo olho de peixe, que projetam uma imagem hemisférica de baixo para cima do dossel, através de detetores de sílica. A unidade de controle recebe e registra os dados do sensor 
e executa os cálculos necessários para a determinação dos parâmetros avaliados. A técnica consiste basicamente da combinação de uma medição do "brilho do céu" ("sky brightness"), realizada com o sensor nivelado acima do dossel, com uma série de medições tomadas sob o dossel. O conjunto de lentes realiza leituras de radiação difusa, o que obrigou a tomada das medições serem realizadas sempre ao amanhecer ou entardecer, horas do dia de predominância desse tipo de radiação. Foram tomadas cinco medições abaixo do dossel para cada leitura acima, visto que as leituras de radiação acima do dossel praticamente não apresentavam variação entre medidas sucessivas. Portanto, eram escolhidas dez estações consideradas como representativas da condição média do pasto, e, em cada estação, eram tomadas uma leitura acima e cinco leituras abaixo do dossel (totalizando 50 medidas), sendo tomados, ao término de todas as leituras, os valores médios de IAF, IL e ângulos foliares. As leituras abaixo do dossel eram tomadas localizando o sensor inicialmente na base da touceira e, à medida que o dossel recuperava sua área foliar, as leituras eram tomadas afastando-se o sensor, gradativamente, da base da touceira em direção às áreas entre touceiras. Essa metodologia foi utilizada, principalmente, devido a reduzida área foliar remanescente no resíduo pós-pastejo do tratamento 1. A partir do dia 11 das rebrotas, esse tratamento já permitia o deslocamento do sensor da base da touceira, pois já apresentava alguma área foliar, responsável pela interceptação da luz incidente, base para o cálculo dos valores de IAF, IL e ângulos foliares médios.

As taxas de fotossíntese foliar líquida e temperatura foliar foram medidas utilizando-se um sistema portátil de fotossíntese LI-COR modelo LI 6400 (LI-COR, Lincoln, Nebraska, EUA), que mede taxas líquidas de fotossíntese através da estimativa de assimilação de carbono pelas folhas. Trata-se de um sistema portátil, que permite ao operador leituras instantâneas de fotossíntese líquida, condutância estomática, temperatura foliar, umidade e luz incidente interceptada pela área foliar. O instrumento é composto por um console e câmara ventilada onde é colocada parte de uma folha. No console encontram-se bomba de sucção, reservatório de ar, válvula de ajuste, medidor de fluxo de massa e ar e controlador interno de fluxo. O console é controlado por um microprocessador que também tem a função de processar e armazenar dados. A câmara 
ventilada possui sensor de $\mathrm{CO}_{2}$ e umidade, ventilador, um termopar de referência e outro termopar que toca a face inferior da folha. Um fluxo contínuo de ar é succionado a uma taxa conhecida, o ar é homogeneizado e a concentração de $\mathrm{CO}_{2}$ na saída é medida por um sensor. $\mathrm{O}$ fluxo de $\mathrm{CO}_{2}\left(\mathrm{~F}_{\mathrm{CO} 2}\right)$ que entra na câmara pode ser calculado através da equação:

$$
\mathrm{F}_{\mathrm{CO} 2}=\left(\mathrm{C}_{\mathrm{CO} 2}^{\mathrm{C}}-\mathrm{C}^{\mathrm{E}} \mathrm{CO} 2\right) \cdot \mathrm{Q}
$$

onde: $\mathrm{C}_{\mathrm{CO} 2}^{\mathrm{C}}$ e $\mathrm{C}^{\mathrm{E}}{ }_{\mathrm{CO} 2}$ são as concentrações de $\mathrm{CO}_{2}$ do ar $\left(\mathrm{mg} \mathrm{m}^{-3}\right)$ que sai e que entra na câmara, respectivamente. O fator $\mathrm{Q}$ é a taxa de fluxo volumétrico de ar que passa pela câmara $\left(\mathrm{m}^{3} \mathrm{~s}^{-1}\right)$.

Considerando que a única fonte de $\mathrm{CO}_{2}$ no interior da câmara é o ar que entra na mesma, a densidade de fluxo de fotossíntese $\mathrm{J}_{\mathrm{CO} 2}\left(\mathrm{mg} \mathrm{cm}^{-2}\right)$ será igual a $\mathrm{F}_{\mathrm{CO} 2} / \mathrm{A}$, onde A é a área $\left(\mathrm{cm}^{2}\right)$ da folha contida no interior da câmara. Assim,

$$
\mathrm{F}_{\mathrm{CO} 2}=\mathrm{A} \cdot\left(\mathrm{C}_{\mathrm{CO} 2}^{\mathrm{C}}-\mathrm{C}^{\mathrm{E}} \mathrm{CO} 2\right) /\left(\mathrm{r}_{\mathrm{CO} 2}^{\mathrm{f}}+\mathrm{r}_{\mathrm{CO} 2}^{\mathrm{c}}\right)
$$

onde: $\mathrm{r}_{\mathrm{CO} 2}^{\mathrm{f}}$ e $\mathrm{r}^{\mathrm{c}}{ }_{\mathrm{CO} 2}$ são, respectivamente, as resistência à difusão de $\mathrm{CO}_{2}$ da folha e do ar da câmara.

Para cada unidade experimental, foram realizadas 30 medições de fotossíntese foliar líquida e de temperatura foliar. Cada medição instantânea durava em média 1 minuto para total estabilização. Como eram realizadas medições em três piquetes (tratamentos) por dia de amostragem, totalizou-se 90 medições por dia. Antes das medições, era fixado um nível de radiação no interior da câmara, objetivando eliminar o efeito de variações na quantidade e qualidade da radiação incidente, visto que as medições e transporte do aparelho entre os piquetes e entre as estações de medições, duravam em torno de 100 minutos, o que, geralmente acarretava em variações na quantidade de radiação natural incidente.

As medições tinham início sempre por volta das 9:30h da manhã, horário mais indicado fisiologicamente para tomadas de medidas de fotossíntese, visto que é nesse horário que se tem o pico de turgidez dos estômatos e os níveis de radiação incidentes ainda não são inibitórios à fotossíntese, como os níveis próximos ao horário de pico (12:00h). Os valores de radiação fixados no interior da câmara foram diferentes de acordo com a estação do ano e, seguiram a observação de um valor médio tomado no 
"quantum sensor" do aparelho, sempre no horário do início das medições. Para a primavera-verão foi utilizado o valor de $2.200 \mu \mathrm{mol}$ de fótons $\mathrm{m}^{-2} \mathrm{~s}^{-1}$, enquanto no outono-inverno, esse valor foi reduzido para $1.500 \mu \mathrm{mol}$ de fótons $\mathrm{m}^{-2} \mathrm{~s}^{-1}$. As medições eram tomadas em folhas mais novas completamente expandidas, oriundas de touceiras representativas da condição média da pastagem.

A massa de forragem (MF) foi medida, em outro experimento realizado na mesma área experimental (Penati, 2002), no $1^{\underline{0}}$ e $33^{\circ}$ dia de cada rebrota, determinada por método direto como a média de 5 pontos de amostragem cortados ao longo de uma linha transecta. Em cada ponto, a altura do dossel foi medida e, em seguida a forragem contida dentro de uma moldura de $1 \mathrm{~m}^{2}$ foi cortada ao nível do solo. Uma sub-amostra era pesada fresca no campo, levada para secar em estufa de ar forçado a $55^{\circ} \mathrm{C}$ por $72 \mathrm{~h}$, e em seguida pesada novamente. O teor de MS era então calculado e usado para estimar a MF da amostra. Com os dados de altura e MF no $1^{-0}$ e $33^{\circ}$ dia de todas as rebrotas (ciclos de pastejo), a relação entre altura do dossel e MF foi estabelecida através de regressão linear utilizando os procedimentos PROC REG e PROC SORT do pacote estatístico SAS (SAS Institute, 1988) para estimativa de MF no $11^{\circ}$ e $22^{\circ}$ dias. As taxas de acúmulo de forragem ( $\mathrm{kg} \mathrm{MS} \mathrm{ha}{ }^{-1} \mathrm{dia}^{-1}$ ) foram calculadas pelas diferenças entre os valores de MF entre os dias 1 e 11; 11 e 22 e 22 e 33, para cada tratamento, dentro dos ciclos de pastejo.

Os dados foram analisados seguindo a estrutura de parcelas sub-sub-divididas, em blocos casualizados, com 4 repetições, sendo considerados os tratamentos como parcelas, os ciclos de pastejo (ciclos) como sub-parcelas e os dias de observação (dias) como sub-sub-parcelas. A análise foi realizada através do procedimento MIXED (“PROC MIXED”) do pacote estatístico SAS (SAS Institute, 1988). Após a análise da variância resultante do procedimento MIXED, foi utilizado o PROC REG (SAS Institute, 1988), para a obtenção das análises de regressão das interações significativas de interesse. Foram realizadas, ainda, análises de correlação parcial entre as respostas, através do comando "REPEATED" do procedimento GLM ("PROC GLM")(SAS Institute, 1988). Para todas as análises, foi considerado como nível de significância $5 \%$ de probabilidade. 


\section{RESULTADOS E DISCUSSÃO}

\subsection{Altura média do dossel}

A análise da variância identificou efeitos de altura média do dossel para tratamento ( $\mathrm{P}=0,0001)$, ciclo de pastejo (ciclo) $(\mathrm{P}=0,0001)$, dia de rebrota (dia) $(\mathrm{P}=0,0001)$, e para as interações tratamentoxciclo $(\mathrm{P}=0,0041)$ e cicloxdia $(\mathrm{P}=0,0001)$ (Figura 1 e Tabela 3).

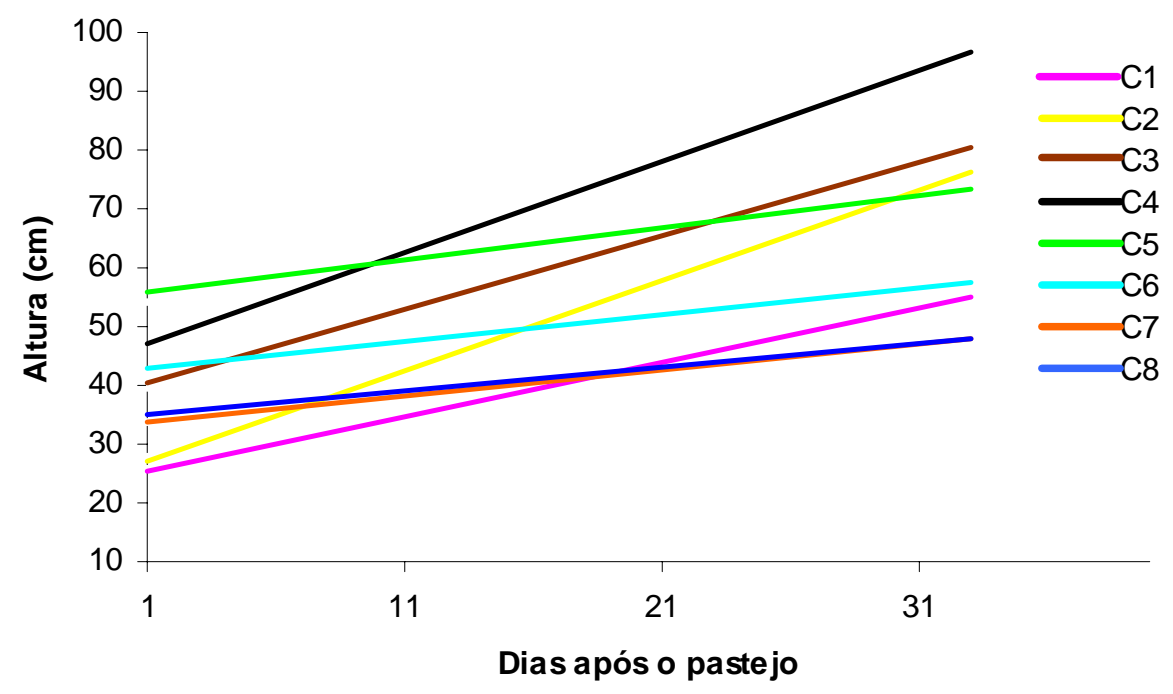

Figura 1 - Regressões lineares simples entre altura média do dossel e dias de rebrota nos ciclos de pastejo.

Foi verificado correlação positiva $(\mathrm{P}=0,0001)$ entre altura e massa de forragem, indicando que à medida que o dossel aumenta em altura, há um acompanhamento em seus valores de massa de forragem. Estes resultados são equivalentes aos de Canto et al. 
(2001) que observaram, também em capim Tanzânia, aumentos lineares nos valores de massa de forragem em função da altura do pasto.

Tabela 3. Regressões lineares de altura média do dossel de capim Tanzânia, em função de dias de rebrota, para os 8 ciclos de pastejo (média de 3 tratamentos e 4 repetições)

\begin{tabular}{ccccc}
\hline Ciclo de pastejo & Equação & $\mathrm{R}^{2}$ & Erro padrão $(\mathrm{cm})$ & $\mathrm{CV}(\%)$ \\
\hline 1 & $\mathrm{~h}=24,6+0,9$ dia & 0,9794 & 2,2 & 5,6 \\
2 & $\mathrm{~h}=25,6+1,5 \mathrm{dia}$ & 0,9979 & 1,2 & 2,3 \\
3 & $\mathrm{~h}=39,0+1,2 \mathrm{dia}$ & 0,9811 & 2,9 & 4,9 \\
4 & $\mathrm{~h}=45,3+1,6 \mathrm{dia}$ & 0,9319 & 7,1 & 9,9 \\
5 & $\mathrm{~h}=55,3+0,5 \mathrm{dia}$ & 0,9553 & 2,0 & 3,1 \\
6 & $\mathrm{~h}=42,4+0,4 \mathrm{dia}$ & 0,9880 & 0,8 & 1,7 \\
7 & $\mathrm{~h}=33,2+0,4 \mathrm{dia}$ & 0,9948 & 0,5 & 1,3 \\
8 & $\mathrm{~h}=34,7+0,4 \mathrm{dia}$ & 0,9454 & 1,6 & 3,9 \\
\hline
\end{tabular}

$\mathrm{h}=$ altura média do dossel; dia = dia após o pastejo

A altura média do dossel apresentou correlação negativa com a interceptação luminosa (IL) por unidade de área de folha $(\mathrm{P}=0,0486)$. Entretanto, a IL de dossel apresenta um aumento, já que as folhas mais eretas passam a ter uma maior eficiência de utilização de luz e assimilação líquida total de $\mathrm{CO}_{2}$ (Warren-Wilson, 1961), promovendo, com isso, maiores acúmulos de forragem e, consequentemente, maiores alturas médias de dossel (Figura 2). A IL apresentou aumentos de maneira assintótica até valores próximos de 95\%, quando os valores de altura média do dossel situavam-se em torno de $55 \mathrm{~cm}$. 


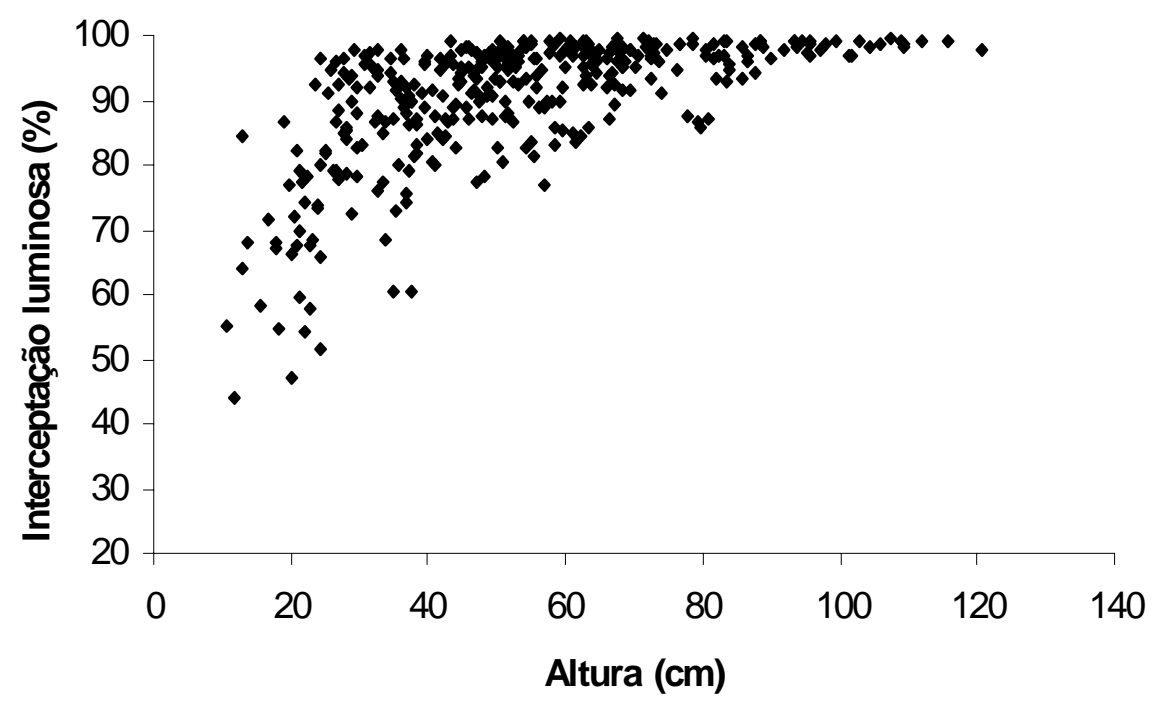

Figura 2 - Altura média e interceptação luminosa do dossel de pastagens de capim Tanzânia ao longo de 8 ciclos de pastejo (Médias de 3 tratamentos e 4 repetições).

Foi observada variação na altura média do pasto em todos os ciclos de pastejo, entre os dias pós-pastejo, principalmente no $1^{\underline{0}}$ e $33^{\underline{0}}$ dia. A variação entre os tratamentos na altura pré-pastejo, pode ser atribuída às diferentes taxas de crescimento para cada ciclo de pastejo, em função da estação do ano correspondente, bem como das diferenças entre as alturas pós-pastejo, já que o dossel iniciou a rebrota sempre de massas de forragem pré-determinadas (tratamentos). Já a variação nas alturas médias no pós-pastejo (dia 1 da rebrota) foram determinadas pelo manejo (taxas de lotação) adotado para impor os tratamentos. Diferenças de pressão de pastejo afetam a densidade do dossel (Hyder, 1972; Matches, 1992), visto que a quantidade de forragem presente em cada piquete correspondia aos tratamentos impostos, o que promoveu diferentes alturas médias para cada ciclo de pastejo. Em Cynodon spp., também foram constatadas 
essas variações na densidade do pasto relacionadas à altura. Trabalhando com Florakirk (Carnevalli et al., 2000), Tifton 85 (Carnevalli et al., 2001a) e Coastcross (Carnevalli et al., 2001b), os autores observaram que, sob alturas constantes, os cultivares apresentaram diferenças na densidade da pastagem ao longo do ano.

\subsection{Fotossíntese foliar líquida e temperatura foliar}

As taxas de fotossíntese foliar líquida (FFL) e a temperatura foliar (TF) foram afetadas por ciclo de pastejo $(\mathrm{P}=0,0001)$, por dia decorrido após o pastejo $(\mathrm{P}=0,0420)$ e pela interação cicloxdia $(\mathrm{P}=0,0001)($ Figuras 3 e 4).

A variação climática ao longo das estações do ano, interferiu nessas respostas, visto que o experimento teve início na primavera-verão (maiores temperaturas e fotoperíodos; Tabela 2), se prolongando até o final do inverno, onde a redução das taxas fotossintéticas (Figura 3) acompanhou as quedas nas temperaturas médias (Figura 4), o que está de acordo com a literatura, que menciona uma temperatura ótima para fotossíntese líquida de folhas em espécies de Panicum, em torno de $35{ }^{\circ} \mathrm{C}$ (Ludlow \& Wilson, 1971; Oberhuber \& Edwards, 1993; Chacón-Moreno et al., 1995; Mello et al., 2001a).

Os quatros primeiros ciclos de pastejo apresentaram temperaturas médias de folhas acima de $30{ }^{\circ} \mathrm{C}$, enquanto que nos quatro últimos, essas temperaturas apresentaram médias abaixo desse valor, chegando a apresentar no ciclo 8 uma média de $24{ }^{\circ} \mathrm{C}$ (Figura 4). Com isso, decresceram também os valores médios de fotossíntese líquida, apresentando nos ciclos de verão valores em torno de 32,1; 36,9 e 39,0 $\mu$ mol $\mathrm{CO}_{2} \mathrm{~m}^{-2} \mathrm{~s}^{-1}$ e no último ciclo decaindo para $11,0 \mu \mathrm{mol} \mathrm{CO}_{2} \mathrm{~m}^{-2} \mathrm{~s}^{-1}$.

Os dias de rebrota não apresentaram efeito nas taxas fotossintéticas e temperaturas foliares, ou seja, em qualquer fase (dia) das rebrotas, essas respostas apresentaram-se de maneira semelhante nas avaliações. Isto foi devido, provavelmente,

por as medições terem sido realizadas sempre em uma mesma categoria de folha (a mais nova do perfilho, completamente expandida), o que promoveu valores semelhantes tanto entre tratamentos como entre os dias de rebrota. 


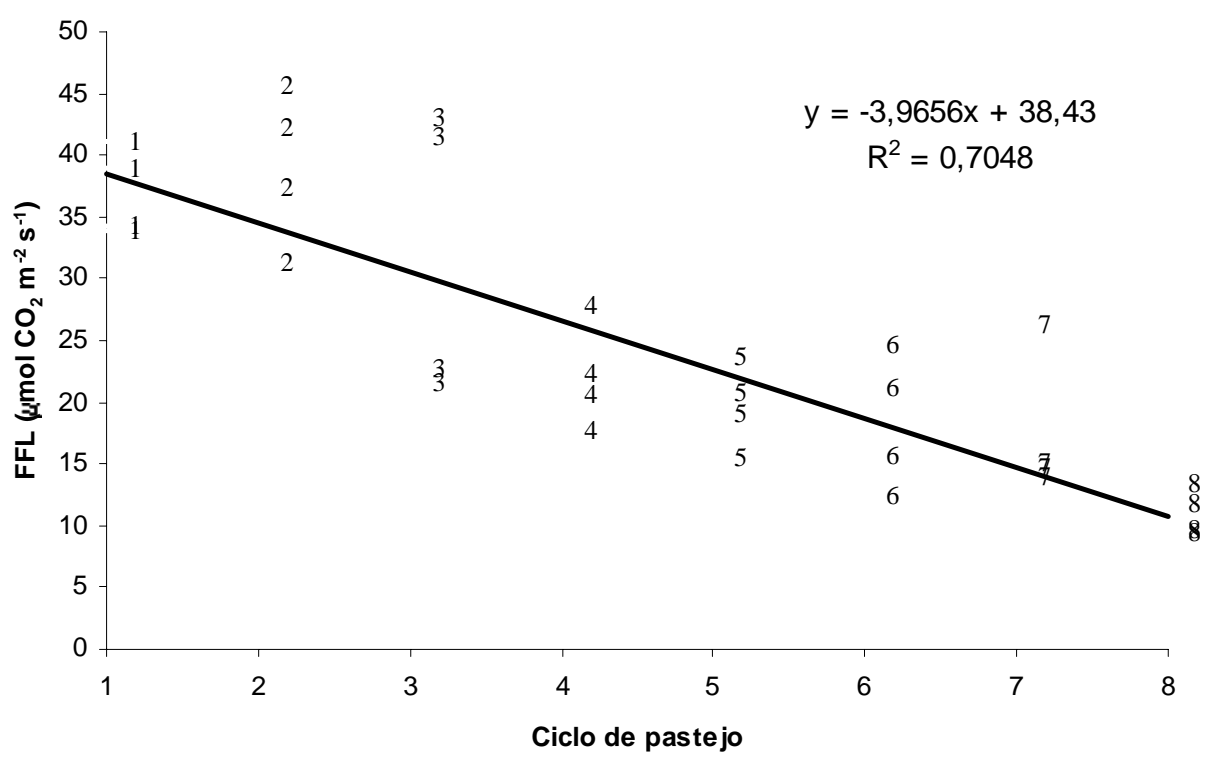

Figura 3 - Respostas fotossintéticas de folhas (Fotossíntese foliar líquida, FFL) de capim Tanzânia a ciclos de pastejo na estação (Média de 3 tratamentos, 4 repetições e 4 datas após o pastejo).

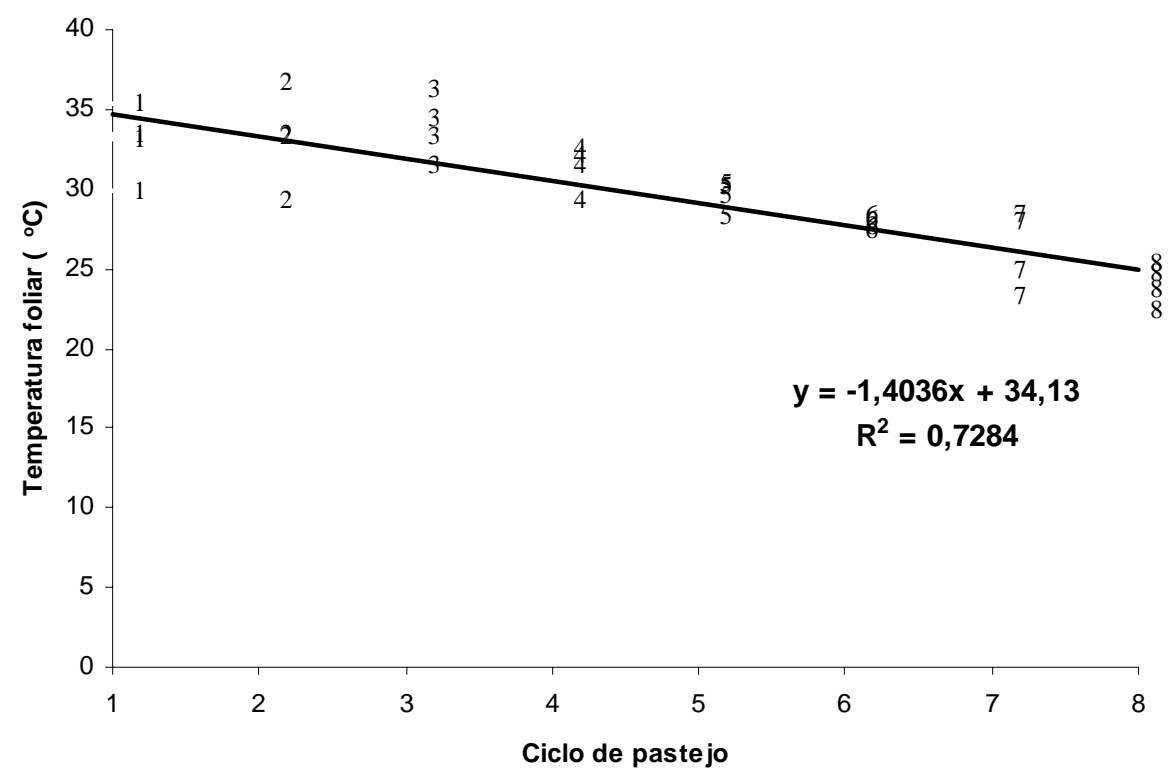

Figura 4 - Temperaturas médias de folhas de capim Tanzânia nos ciclos de pastejo durante a estação (Médias de 3 tratamentos, 4 repetições e 4 datas após o pastejo). 
Nos três tratamentos, os valores de taxa fotossintética, de maneira geral, foram mais reduzidos nos dias 1 e 33 que nos dias intermediários. Uma possível explicação para isso, é que, no primeiro dia, as folhas que restaram após o pastejo encontravam-se, geralmente cortadas ou rasgadas e, no dia 33, estas encontravam-se em um estádio de desenvolvimento além do ideal em termos de taxas fotossintéticas máximas (completamente expandidas), pois a partir deste estádio, as folhas tornam-se fonte de metabólitos para outras partes da planta, o que promoveu os valores de fotossíntese mais reduzidos nesse dia. Segundo Taiz \& Zeiger (1998), a conversão de uma folha de dreno para fonte é gradual e acompanha o processo de maturação. Brown et al. (1966) observaram que plantas de trevo branco com idades de 1 e 2 semanas acumularam mais matéria seca e absorveram mais $\mathrm{CO}_{2}$ que plantas com 3 e 4 semanas de rebrota, demonstrando assim, que folhas mais velhas apresentam taxas fotossintéticas mais reduzidas quando comparadas com folhas recém expandidas (Jewiss \& Woledge, 1967). Já nos dias intermediários, as folhas já haviam se recuperado do estresse do pastejo, e outras folhas já apresentavam seu máximo potencial fotossintético, com taxas de fotossíntese elevadas. Como outros fatores que influenciam as taxas fotossintéticas, tais como temperatura foliar e umidade no solo não sofreram grandes variações entre os dias após pastejo dentro de um mesmo ciclo, é provável que o estado físico juntamente com a idade da folha, tenham sido os responsáveis por essa variação entre os dias após o pastejo.

\section{3 Índice de área foliar (IAF)}

$\mathrm{O}$ índice de área foliar (IAF) foi afetado por tratamento ( $\mathrm{P}=0,0001)$, por ciclo de pastejo $(\mathrm{P}=0,0001)$, por dia decorrido após o pastejo $(\mathrm{P}=0,0001)$, e pelas interações tratamento $\times$ ciclo $(\mathrm{P}=0,0001)$, tratamento $\times$ dia $(\mathrm{P}=0,0002)$ e ciclo $\times$ dia $(\mathrm{P}=0,0001)$.

Os resultados apontam redução nos valores de IAF médio à medida que os ciclos de pastejo avançam, ou seja, da primavera-verão para o outono-inverno (Figura 5). Marshall (1987) destacou a importância dos fatores ambientais, principalmente 
temperatura, fotoperíodo e luz, na taxa de aparecimento de folhas, favorecendo assim, esse modelo estacional da dinâmica de crescimento do IAF.

A dinâmica do IAF do capim Tanzânia irrigado, em função do acúmulo de Unidades Fototérmicas (UF), índice climático que expressa a interação entre temperatura e fotoperíodo, foi avaliada por Mello et al. (2001b). Os autores inferiram que a UF é uma variável adequada para estimar a variação do IAF do capim Tanzânia, durante a rebrota, permitindo a estimativa do crescimento do IAF dessa espécie em diversas regiões com diferentes condições climáticas.

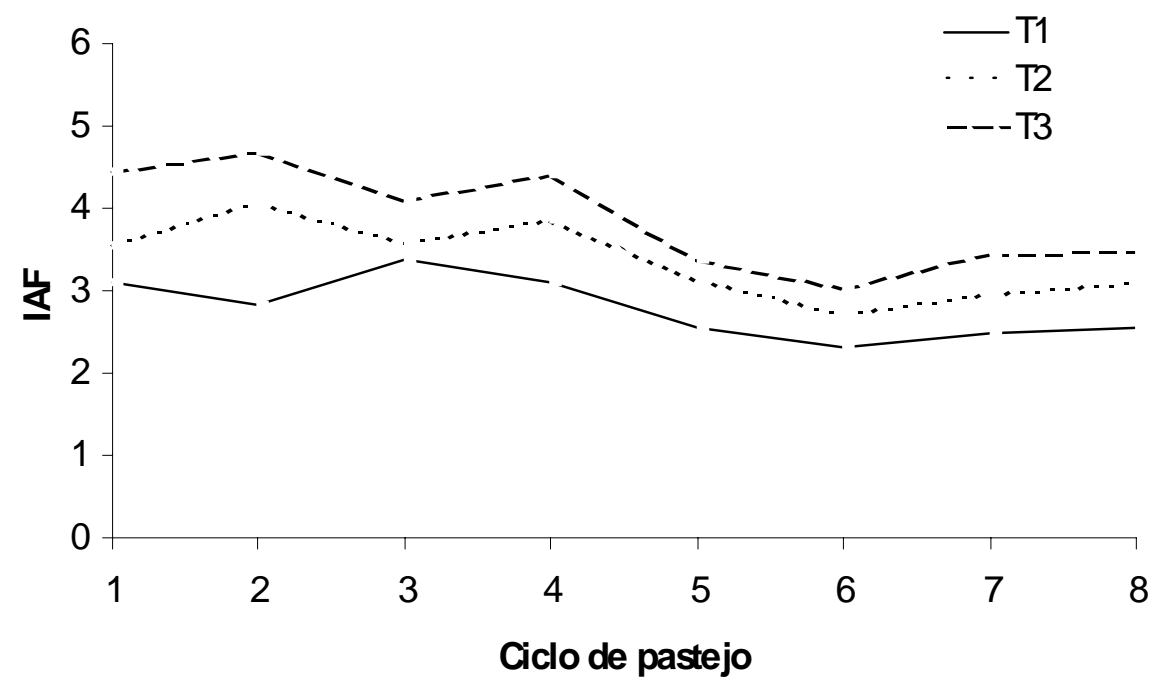

Figura 5 - Índice de área foliar (IAF) de pastos de capim Tanzânia ao longo de 8 ciclos de pastejo (Média de 4 datas pós-pastejo e 4 repetições).

Para os três tratamentos, houve crescimento linear do IAF médio, ao longo do avanço das rebrotas (Figura 6 e Tabela 4). Esse tipo de resposta está de acordo com a literatura, que reporta aumentos lineares do IAF médio, à medida que eleva-se o número de dias de rebrota, em função de taxas crescentes de fotossíntese de dossel (Brown \& Blaser, 1968; Costa et al., 1999). Os valores de IAF médio mais altos ocorreram no tratamento 3, em função da maior quantidade de massa seca residual. Nesse tratamento, 
o IAF médio, no pós-pastejo, foi de 2,7 , enquanto nos tratamentos 2 e 1 , os valores médios de IAF foram 2,2 e 1,4 , respectivamente, também no $1^{\underline{0}}$ dia da rebrota. $\mathrm{O}$ tratamento 3 chegou a apresentar valor médio de IAF de 6,1 no $33^{\circ}$ dia da rebrota, no primeiro ciclo de pastejo. As médias dos oito ciclos de pastejo para o $33^{\underline{0}}$ dia foram 4; 4,6 e 5, respectivamente para os tratamentos de 1.000, 2.500 e $4.000 \mathrm{~kg} \mathrm{MSV} \mathrm{ha}^{-1}$.

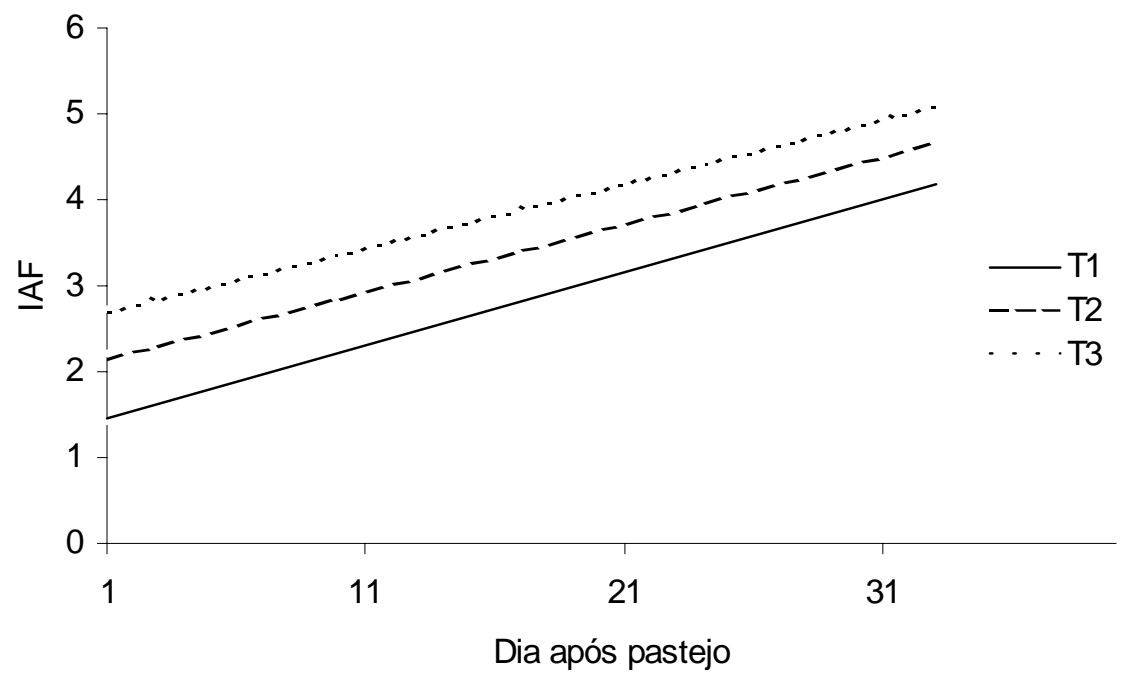

Figura 6 - Índice de área foliar (IAF) de pastos de capim Tanzânia nas 4 datas póspastejo (Média de 8 ciclos de pastejo e 4 repetições).

Tabela 4. Regressões lineares entre tratamentos e dias de avaliação para índice de área foliar (IAF) de capim Tanzânia (Médias de 8 ciclos de pastejo e 4 repetições).

\begin{tabular}{ccccc}
\hline \multirow{2}{*}{ Tratamento } & \multicolumn{4}{c}{ IAF } \\
\cline { 2 - 5 } & Equação & $\mathrm{R}^{2}$ & Erro padrão & CV (\%) \\
\hline 1 & IAF $=1,4+0,1$ dia & 0,9665 & 0,3 & 9,6 \\
2 & IAF $=2,1+0,1$ dia & 0,9743 & 0,2 & 6,3 \\
3 & IAF $=2,6+0,1$ dia & 0,9808 & 0,2 & 4,5 \\
\hline
\end{tabular}

dia = dia após o pastejo 
Aumentos de IAF estiveram correlacionados aos aumentos de IL (Figura 7), indicando que à medida que se eleva a quantidade de folhas na pastagem, o dossel intercepta maior quantidade de luz, o que está de acordo com a literatura, que indica crescimentos lineares de IL em função do aumento do IAF médio (Brown \& Blaser, 1968; Hay \& Walker, 1989). A IL aumentou de maneira assintótica até valores próximos de 95\%, correspondendo a valores de IAF médio em torno de 3,5.

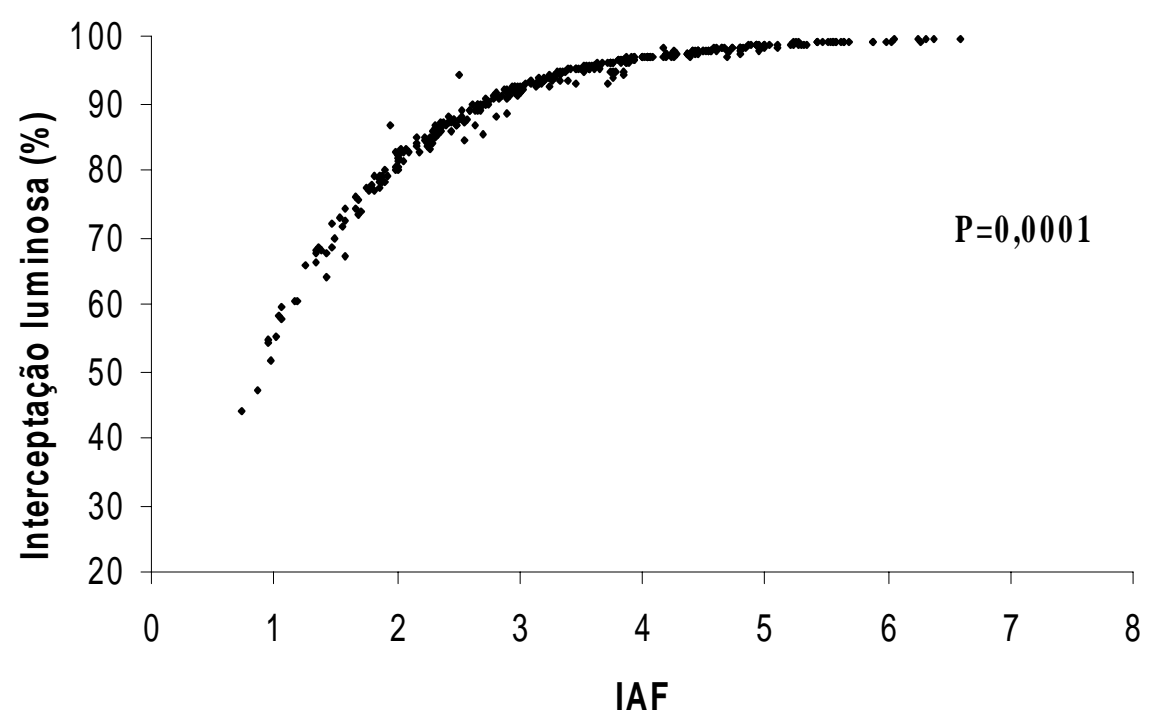

Figura 7 - Índice de área foliar (IAF) e interceptação luminosa de pastos de capim Tanzânia ao longo de 8 ciclos de pastejo (Média de 3 tratamentos e 4 repetições).

\section{4 Ângulos foliares médios}

Os ângulos foliares médios foram afetados por ciclo de pastejo $(\mathrm{P}=0,0005)$, por dia decorrido após o pastejo $(\mathrm{P}=0,0001)$, e pelas interações tratamento $\times$ ciclo $(\mathrm{P}=0,0259)$, tratamento $\times$ dia $(\mathrm{P}=0,0001)$ e ciclo $\times$ dia $(\mathrm{P}=0,0001)$.

À medida que houve o avanço da estação (ciclos), ocorreu redução nos ângulos foliares médios (médias das quatro datas durante a rebrota) em resposta ao pastejo 
(Figura 8 e Tabela 5). No tratamento de menor resíduo de massa seca verde pós-pastejo (1.000 $\mathrm{kg} \mathrm{ha}^{-1}$ ), as plantas apresentaram essa modificação morfológica para, provavelmente, tentar compensar a reduzida área fotossinteticamente ativa com maior interceptação de luz por unidade de área de folha (Kidd, 1966; Hyder, 1972; Matches, 1992).

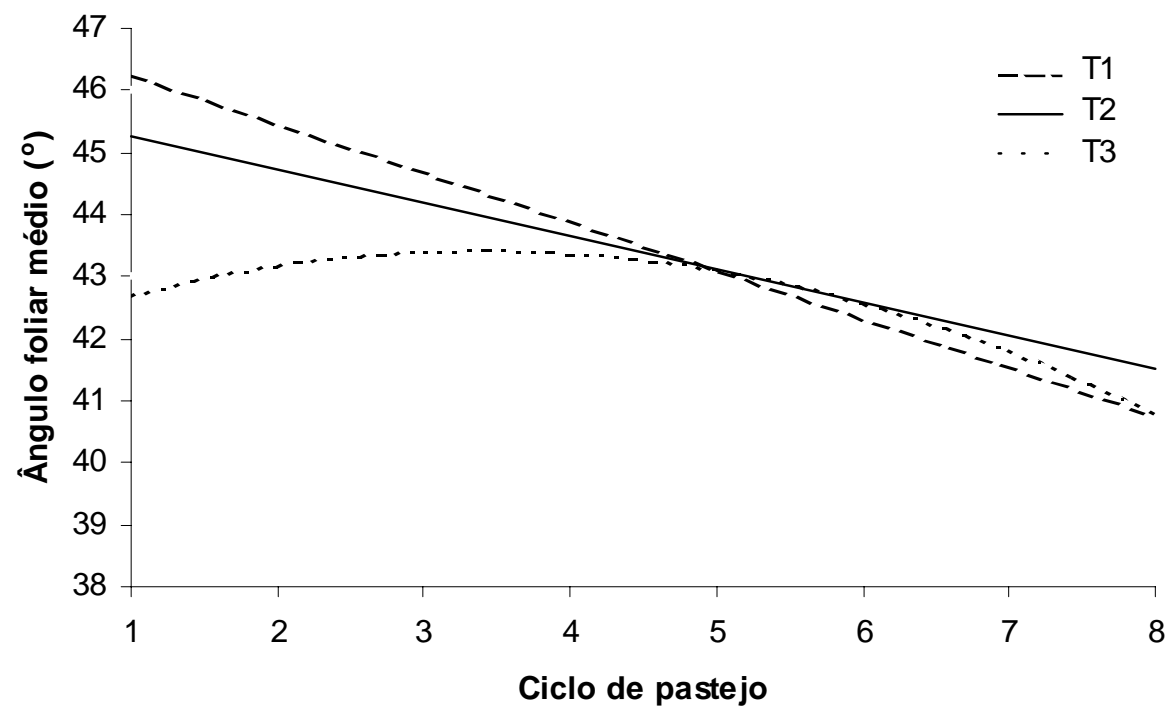

Figura 8 - Ângulo foliar médio de pastos de capim Tanzânia ao longo de 8 ciclos de pastejo (Média de 4 datas pós-pastejo e 4 repetições).

Tabela 5. Regressões lineares e quadrática entre tratamentos e ciclos de pastejo para ângulos foliares médios de capim Tanzânia (Média de 4 idades de rebrota e 4 repetições) .

\begin{tabular}{ccccc}
\hline \multirow{2}{*}{ Tratamento } & \multicolumn{4}{c}{ Angulos foliares médios (AFM) } \\
\cline { 2 - 5 } & Equação & $\mathrm{R}^{2}$ & Erro padrão $\left(^{\circ}\right)$ & $\mathrm{CV}(\%)$ \\
\hline 1 & $\mathrm{AFM}=47,0-0,8$ ciclo & 0,5694 & 1,8 & 4,2 \\
2 & $\mathrm{AFM}=45,6-0,5$ ciclo & 0,5046 & 1,3 & 3,0 \\
3 & $\mathrm{AFM}=42,3+0,7$ ciclo $-0,1$ ciclo $^{2}$ & 0,6989 & 0,6 & 1,5 \\
\hline
\end{tabular}

ciclo $=$ ciclo de pastejo 
Kidd (1966), trabalhando com duas taxas de lotação (alta e baixa) em azevém perene, constatou que plantas severamente pastejadas (alta taxa de lotação), rapidamente assumiram um hábito de crescimento prostrado, demonstrado por um perfilhamento horizontal, originário da porção basal das plantas. Avaliando a produtividade e a percentagem de conversão de energia luminosa em energia química em populações de azevém perene, Rhodes (1971) observou que, sob cortes freqüentes, os acessos mais produtivos apresentaram altos coeficientes de extinção luminosa e altos valores de IAF na região basal do dossel. Essa adaptação das plantas, provavelmente, tem o objetivo de compensar a área foliar reduzida, através de maior interceptação de luz por área de folha e, consequentemente, maior eficiência fotossintética. Aguiar (2000), em revisão sobre o uso de plantas forrageiras do grupo Panicum sob lotação rotacionada, citou que, aplicando-se altas pressões de pastejo, com baixas massas de forragem pós-pastejo, ocorre alteração morfológica na planta forrageira, que passa a desenvolver os perfilhos mais na posição horizontal, colocando as folhas e seus pontos de crescimento em posição mais difícil de serem eliminados pela desfolha.

No presente estudo, nos pastos sob desfolha menos intensa, essa redução nos valores dos ângulos com o avanço da rebrota, pode ter ocorrido, provavelmente, em função de uma alta taxa de expansão foliar - já que a quantidade de massa seca residual nesses tratamentos foi suficiente para que a pastagem iniciasse seu acúmulo de forragem mais rapidamente que o tratamento de menor massa seca residual, além de receber os benefícios da irrigação e dos altos níveis de adubação nitrogenada (Wilson, 1975; Lemaire \& Chapman, 1996), promovendo o arqueamento das folhas devido ao seu peso.

A resposta quadrática para o tratamento de maior nível de matéria seca residual (Figura 8) pode ser explicada em função dos valores médios dos ângulos nos ciclos de pastejo, a partir do resíduo pós-pastejo (dia 1). Enquanto os tratamentos 1 e 2 apresentaram valores médios de ângulos nesse dia de 52 e $48^{\circ}$, respectivamente, as folhas do tratamento 3 apresentaram ângulos médios de $45^{\circ}$, ou seja, folhas mais horizontais, principalmente devido à maior massa de forragem pós-pastejo. Outro motivo para esta resposta mais lenta, pode estar relacionado à não necessidade daquela adaptação morfológica citada para o tratamento 1, devido à grande quantidade de folhas 
fotossinteticamente ativas que permaneciam na pastagem desse tratamento após o pastejo. Com isso, a redução nos valores dos ângulos foi menos acentuada ao longo da estação, embora com valores médios próximos ao final de cada ciclo (dia 33). Portanto, a maior diferença entre os valores de ângulos médios dos tratamentos, foi registrada somente no dia 1 das rebrotas.

A análise de correlação parcial indicou correlação positiva $(\mathrm{P}=0,0508)$ entre ângulos foliares médios e massa de forragem, indicando que, com valores médios dos ângulos foliares mais altos (folhas eretas), o dossel apresenta uma maior eficiência de utilização da energia luminosa incidente, maiores taxas de fotossíntese de dossel e, consequentemente, maior produção de matéria seca (Warren-Wilson, 1961; Duncan, 1971; Hay \& Walker, 1989; Bernardes \& Lima, 2000). Como resultado desse maior acúmulo de forragem, tem-se maior altura do dossel, corroborando o resultado da correlação positiva dos ângulos com a altura média da pastagem.

\subsection{Interceptação Luminosa}

A interceptação luminosa do dossel (IL) foi afetada por tratamento $(\mathrm{P}=0,0001)$, por ciclo de pastejo ( $\mathrm{P}=0,0199)$, por dia decorrido após o pastejo $(\mathrm{P}=0,0001)$, e pela interação tratamento $\times$ ciclo $\times$ dia $(\mathrm{P}=0,0088)$.

Foi observado, para os três tratamentos, resposta linear crescente da IL à medida que as rebrotas (ciclos de pastejo) avançavam (Figura 9 e Tabela 5). Essa resposta está de acordo com a literatura (Pearce et al., 1965; Rhodes, 1973; Marshall, 1987; Hay \& Walker, 1989), na qual há relatos de aumento crescente do IAF ao longo do tempo e, consequentemente, da quantidade de folhas que irão interceptar a radiação incidente, até

alcançarem valores de IL próximos de 95\%, quando, a partir daí, a proporção do total de folhas ao longo do perfil que recebe luz, começa a diminuir, devido ao sombreamento das folhas inferiores pelas superiores, reduzindo a taxa de acúmulo líquido de forragem. Com isso, os valores médios de IL demonstraram uma variação mais proeminente entre os tratamentos, apenas nos dias 1 e 11 de cada ciclo de pastejo. No dia 22, os três tratamentos já haviam atingido valores próximos a 95\% de IL (Figura 9). 


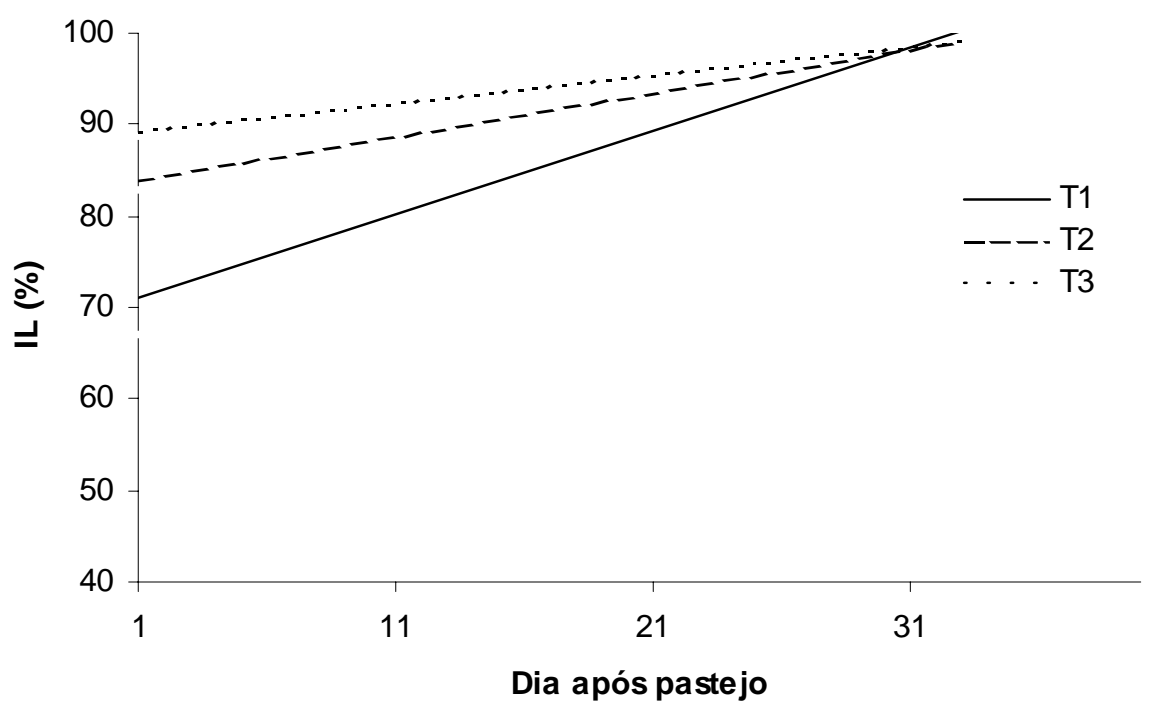

Figura 9 - Interceptação luminosa (IL) de pastos de capim Tanzânia nas 4 datas póspastejo (Média de 8 ciclos de pastejo e 4 repetições).

Entre as intensidades de pastejo, os valores de IAF crítico (95\% de IL) foram de 3,3 (T1), 3,8 (T2) e 4,2 (T3), todos alcançados por volta do $22^{\circ}$ dia após o pastejo. Nesse dia das rebrotas, os tratamentos apresentaram valores médios de IL de 94,6; 96,1 e $97,1 \%$, respectivamente para os tratamentos 1,2 e 3 . Valores de IAF crítico próximos aos observados para T2, foram encontrados por Fagundes et al. (1999), trabalhando com Tifton 85. Os autores relataram valores máximos de IAF médio de 3,7. Brougham (1958) encontrou valores de IAF, para 95\% de IL, de 5 e 3,5 para azevém e trevo branco, respectivamente. Humphreys (1991) relatou que, de maneira geral em pastagens, valores de IAF crítico situam-se normalmente entre 3 e 5 . 
Tabela 6. Regressões lineares entre tratamentos, ciclos de pastejo e dias após o pastejo para interceptação luminosa (IL) de capim Tanzânia (Média de 4 repetições).

\begin{tabular}{|c|c|c|c|c|}
\hline & \multicolumn{4}{|c|}{$\mathrm{IL}$} \\
\hline & Equação & $\mathrm{R}^{2}$ & Erro padrão (\%) & $\mathrm{CV}(\%)$ \\
\hline $\mathrm{T} 1 \mathrm{C} 1$ & $\mathrm{IL}=64,4+1,2 \mathrm{dia}$ & 0,7899 & 10,8 & 12,7 \\
\hline $\mathrm{T} 1 \mathrm{C} 2$ & $\mathrm{IL}=64,7+1,1 \mathrm{dia}$ & 0,8869 & 6,4 & 7,6 \\
\hline $\mathrm{T} 1 \mathrm{C} 3$ & $\mathrm{IL}=80,4+0,6 \mathrm{dia}$ & 0,8949 & 3,2 & 3,5 \\
\hline $\mathrm{T} 1 \mathrm{C} 4$ & $\mathrm{IL}=77,2+0,7 \mathrm{dia}$ & 0,8616 & 4,8 & 5,4 \\
\hline T1C5 & $\mathrm{IL}=68,0+0,9 \mathrm{dia}$ & 0,9356 & 5,6 & 6,7 \\
\hline T1C6 & $\mathrm{IL}=66,4+0,9 \mathrm{dia}$ & 0,9206 & 5,0 & 6,1 \\
\hline $\mathrm{T} 1 \mathrm{C} 7$ & $\mathrm{IL}=68,2+1,0 \mathrm{dia}$ & 0,9176 & 6,0 & 7,3 \\
\hline $\mathrm{T} 1 \mathrm{C} 8$ & $\mathrm{IL}=71,5+0,8 \mathrm{dia}$ & 0,8861 & 4,7 & 5,5 \\
\hline $\mathrm{T} 2 \mathrm{C} 1$ & $\mathrm{IL}=72,3+0,9 \mathrm{dia}$ & 0,9095 & 10,8 & 12,3 \\
\hline $\mathrm{T} 2 \mathrm{C} 2$ & $\mathrm{IL}=87,5+0,4 \mathrm{dia}$ & 0,9087 & 2,6 & 2,8 \\
\hline $\mathrm{T} 2 \mathrm{C} 3$ & $\mathrm{IL}=84,8+0,5 \mathrm{dia}$ & 0,9134 & 3,2 & 3,5 \\
\hline $\mathrm{T} 2 \mathrm{C} 4$ & $\mathrm{IL}=90,2+0,3 \mathrm{dia}$ & 0,7944 & 2,2 & 2,3 \\
\hline $\mathrm{T} 2 \mathrm{C} 5$ & $\mathrm{IL}=84,7+0,4 \mathrm{dia}$ & 0,9489 & 2,4 & 2,6 \\
\hline T2C6 & $\mathrm{IL}=78,4+0,6 \mathrm{dia}$ & 0,9637 & 2,6 & 2,9 \\
\hline $\mathrm{T} 2 \mathrm{C} 7$ & $\mathrm{IL}=82,7+0,5 \mathrm{dia}$ & 0,9441 & 2,8 & 3,1 \\
\hline $\mathrm{T} 2 \mathrm{C} 8$ & $\mathrm{IL}=84,0+0,4 \mathrm{dia}$ & 0,8665 & 2,7 & 2,9 \\
\hline $\mathrm{T} 3 \mathrm{C} 1$ & $\mathrm{IL}=87,9+0,4 \mathrm{dia}$ & 0,9320 & 5,6 & 5,9 \\
\hline $\mathrm{T} 3 \mathrm{C} 2$ & $\mathrm{IL}=93,1+0,2 \mathrm{dia}$ & 0,8787 & 1,8 & 1,8 \\
\hline T3C3 & $\mathrm{IL}=89,4+0,3 \mathrm{dia}$ & 0,9153 & 2,8 & 2,9 \\
\hline $\mathrm{T} 3 \mathrm{C} 4$ & $\mathrm{IL}=93,9+0,2 \mathrm{dia}$ & 0,8340 & 1,2 & 1,3 \\
\hline $\mathrm{T} 3 \mathrm{C} 5$ & $\mathrm{IL}=87,7+0,3 \mathrm{dia}$ & 0,9747 & 1,9 & 2,1 \\
\hline Т3С6 & $\mathrm{IL}=84,6+0,4 \mathrm{dia}$ & 0,9456 & 2,5 & 2,7 \\
\hline $\mathrm{T} 3 \mathrm{C} 7$ & $\mathrm{IL}=87,6+0,3 \mathrm{dia}$ & 0,9726 & 1,8 & 1,9 \\
\hline T3C8 & $\mathrm{IL}=88,6+0,3 \mathrm{dia}$ & 0,8675 & 2,0 & 2,1 \\
\hline
\end{tabular}

$\mathrm{T}=$ tratamento; $\mathrm{C}=$ ciclo de pastejo; dia = dia pós-pastejo 
Um dos critérios adotados para o manejo da pastagem, seria o de permitir a entrada dos animais nos piquetes quando os dosséis apresentassem 95\% de IL (Korte et al., 1982; Bueno et al., 2001). Korte et al. (1982) estudaram o crescimento de azevém perene sob quatro intensidades de desfolha baseadas no IAF residual, e duas frequências de pastejo, baseadas na IL (95\% de IL e duas semanas depois de atingido esse valor). Os autores concluíram que, para a fase de desenvolvimento vegetativo, a freqüência de desfolha no ponto onde a planta atinge $95 \%$ de IL é a mais indicada. Contudo, alertaram para a necessidade de cautela no uso dessa freqüência quando a planta encontra-se em estádio de desenvolvimento reprodutivo, pois nesse período, o acúmulo de forragem é fortemente afetado, resultando em maior acúmulo de hastes e material morto na pastagem.

Nas condições do presente experimento (pastagens irrigadas e adubadas com 80

$\mathrm{kg} \mathrm{N} \mathrm{ha}^{-1}$ ciclo $^{-1}$ ), o período de rebrota, baseado no manejo da desfolha sempre que IL = $95 \%$, seria em torno de 22 dias. A questão que surge é se, com esse manejo, pastagens de capim Tanzânia suportariam altas lotações (as quais são necessárias para a rentabilidade do sistema de produção), sem o comprometimento de sua perenidade e produtividade. Korte et al. (1982) demonstraram que pastejos lenientes e freqüentes, resultam na redução da taxa de acúmulo de forragem verde por área, o que, provavelmente, iria acontecer com os tratamentos 2 e 3. No caso do T1, em função de uma reduzida quantidade de material morto, e massa de forragem composta principalmente de folhas (Korte et al., 1982), poderia ocorrer o comprometimento da perenidade da pastagem, se pastejada a cada 22 dias.

\subsection{Acúmulo e taxa de acúmulo líquido de forragem}

Em função do ajuste da taxa de lotação ao longo dos ciclos de pastejo, as quantidades de massa seca residuais médias foram: $\mathrm{T} 1=1.518 ; \mathrm{T} 2=2.902$ e T3=4.220 kg MSV ha ${ }^{-1}$. 
A equação de regressão que melhor ajustou os dados de massa de forragem (MF; kg MSV ha $\left.{ }^{-1}\right)$ e altura média do dossel $(\mathrm{h} ; \mathrm{cm})$ foi:

$$
\mathrm{MF}=941,3+93,0 \mathrm{~h}
$$

$\operatorname{com} \mathrm{R}^{2}=0,57$ e erro padrão da regressão $=2.156,5 \mathrm{~kg} \mathrm{MS} \mathrm{ha}^{-1}$.

Não houve diferença $(\mathrm{P}=0,2008)$ entre os tratamentos para taxa de acúmulo líquido de forragem (TAL; $\mathrm{kg} \mathrm{MS} \mathrm{ha}{ }^{-1} \mathrm{dia}^{-1}$ ), em nenhum dos três períodos das rebrotas ( $\mathrm{P} 1=$ dia 1 ao dia 11; $\mathrm{P} 2$ = dia 11 ao dia 22 e P3 = dia 22 ao dia 33) (Figura 10), nem para acúmulo líquido total de forragem ( $\left.\mathrm{AL} ; \mathrm{kg} \mathrm{MS} \mathrm{ha}^{-1}\right)(\mathrm{P}=0,2144)$ ao longo dos oito ciclos de pastejo, tendo apresentado valores médios entre os tratamentos de 88,7 kg MS $\mathrm{ha}^{-1} \mathrm{dia}^{-1}$ e $21.652 \mathrm{~kg} \mathrm{MS} \mathrm{ha}{ }^{-1} 8 \operatorname{ciclos}^{-1}$, respectivamente para TAL e AL. Fagundes et al. (1999) também não observaram diferenças de taxas de acúmulo, quando avaliaram três cultivares de Cynodon, mantidos sob lotação contínua em quatro alturas (intensidades de pastejo), com valores médios variando de 24,5 a 104,3 $\mathrm{kg} \mathrm{MS} \mathrm{ha}^{-1} \mathrm{dia}^{-1}$. No presente experimento, essa amplitude foi entre 11,6 e 284,8 MS ha ${ }^{-1} \mathrm{dia}^{-1}$. Humphreys (1966), trabalhando com Panicum maximum var. Trichoglume, demonstrou que a intensidade de desfolha não interferiu no crescimento, corroborando os resultados obtidos no presente ensaio.

As TAL apresentaram valores superiores nos quatro primeiros ciclos de pastejo (primavera-verão) em relação aos quatro últimos (outono-inverno), com médias de 129,5 e $48 \mathrm{~kg} \mathrm{MS} \mathrm{ha}{ }^{-1} \mathrm{dia}^{-1}$, respectivamente. Santos et al. (1999), avaliando frequência de pastejo e época do ano sobre a taxa de acúmulo, em dois cultivares de Panicum maximum, também mediram maiores taxas de acúmulo de forragem de capim Tanzânia de novembro a fevereiro. 


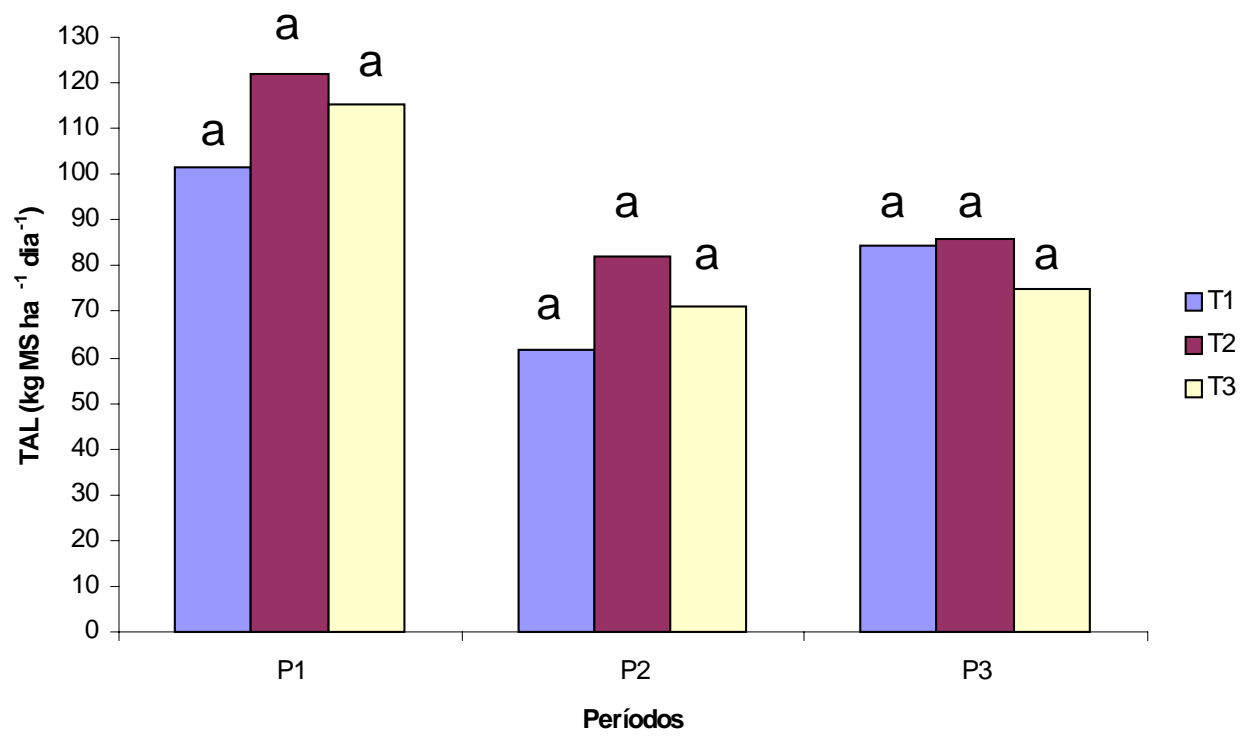

Figura 10 - Taxa de acúmulo líquido de forragem (TAL) de pastos de capim Tanzânia ao longo de 8 ciclos de pastejo, em três períodos de acúmulo. Colunas com médias seguidas por letras diferentes diferem entre si $(\mathrm{P}<0,05)$, segundo o teste de Tukey.

Esses resultados de TAL semelhantes entre tratamentos, demonstram que, o tratamento 1, apesar de apresentar uma quantidade de massa seca pós-pastejo bastante reduzida, foi capaz de compensar essa deficiência ao longo dos ciclos de pastejo, com valores de TAL semelhantes aos dos demais tratamentos, que, por apresentarem massa seca residuais mais elevadas, teoricamente teriam maiores taxas de acúmulo de forragem, principalmente no início das rebrotas. Davies (1974), avaliando a rebrota de azevém perene, em reposta à quantidade de tecido foliar remanescente após desfolha, verificou que a taxa de crescimento das plantas desfolhadas não foi muito menor do que das plantas não desfolhadas. $\mathrm{O}$ autor sugeriu que as plantas forrageiras têm a capacidade de compensar a perda de tecido foliar, pelo aumento na atividade fotossintética das folhas remanescentes, o que pode ser comprovado no presente ensaio, visto que os valores de taxa de fotossíntese líquida de folha no T1 foram próximos aos dos demais tratamentos. 
O acúmulo e a taxa de acúmulo líquido são dados pela diferença entre a síntese de novos tecidos (crescimento) e as perdas por senescência e morte de tecidos (Hodgson, 1990). Os tratamentos 2 e 3, em função da grande quantidade de massa seca póspastejo, apresentaram uma elevada senescência de tecidos com o avanço das rebrotas e, conseqüentemente, acúmulo de material morto, já que as mais baixas taxas de lotação (em relação ao T1) necessárias para a imposição desses tratamentos, promoveram maiores perdas de forragem (Penati, 2002). Além disso, nesses tratamentos, a IL já alcançava 95\% no P2, ou seja, após esse período, a pastagem sofreu esse acúmulo de material senescente. Já no T1, também em função da baixa quantidade de massa seca residual, praticamente toda a matéria seca presente nos piquetes era composta de material verde, pois as altas taxas de lotação utilizadas nesse tratamento, corresponderam a alta eficiência de utilização da forragem produzida (Penati, 2002), não permitindo grandes acúmulos de material senescente. Em função disso, foram observados os altos valores de TAL, com as médias chegando a igualar ao T2 e superar o T3, no período 3, quando o T1 já havia recuperado grande parte de sua área foliar, alcançando altas taxas de fotossíntese líquida do dossel. Outro fator que permitiu esses valores de TAL para o T1, próximos aos observados para o T2 e o T3, foi que no primeiro, ao contrário dos outros dois, o IAF crítico (95\% de IL) foi atingido pouco após o $22^{\circ}$ dia, já no P3, o que fez com que, nesse tratamento, houvesse melhor utilização da radiação incidente, provavelmente sem, ou com pouco balanço negativo de carbono, pois a média de IL no $33^{\circ}$ dia, para o T1, foi de $96,3 \%$, enquanto que nos outros dois tratamentos, valores próximos a esse já eram alcançados no $22^{\underline{0}}$ dia. Brown (1987) demonstrou, para Cynodon dactylon cv. "Coastal", que durante a primeira semana de rebrota, as taxas fotossintéticas, em dosséis cortados mensalmente com grande intensidade, foram menores que em dosséis cortados semanalmente com menor intensidade. Entretanto, na segunda, terceira e quarta semanas de rebrota, as taxas fotossintéticas foram bem maiores nos dosséis cortados mensalmente, explicando assim, a recuperação do $\mathrm{T} 1$ com o avanço das rebrotas.

Os ângulos foliares médios também podem ter influenciado nesses resultados de TAL semelhantes entre os tratamentos. Os altos valores medidos no T1 no dia 1 (folhas 
eretas), permitiram que boa parte da radiação incidente penetrasse até a base das touceiras, favorecendo as taxas de aparecimento de folhas e perfilhos, bem como as de expansão foliar (Lemaire \& Chapman, 1996). Com a posterior redução nos ângulos, com o avanço das rebrotas, houve uma maior IL por unidade de área de folha, favorecendo a TAL para esse tratamento.

Como conseqüência de um maior acúmulo de material morto no T3 e reduzido no T1 (Penati, 2002), os valores de TAL foram mais elevados no T2, que situava-se em uma posição intermediária entre quantidade de massa seca residual (suficiente para TAL altas já a partir do dia 1) e acúmulo de material morto na pastagem.

Essas diferenças entre crescimento e senescência podem ser bem ilustradas na TAL entre os períodos (P1, P2 e P3). Utilizando-se as médias dos três tratamentos, maior TAL $(\mathrm{P}=0,0002)$ foi registrada para o P1 $\left(112,9 \mathrm{~kg} \mathrm{MS} \mathrm{ha}^{-1} \mathrm{dia}^{-1}\right)$, quando comparado aos períodos 2 (71,7 $\left.\mathrm{kg} \mathrm{MS} \mathrm{ha}^{-1} \mathrm{dia}^{-1}\right)$ e $3\left(81,7 \mathrm{~kg} \mathrm{MS} \mathrm{ha}^{-1} \mathrm{dia}^{-1}\right)$. No período 1 (dia 1 ao 11), quando se iniciava o acúmulo de forragem a partir das quantidades de massa seca residuais impostas pelos tratamentos, a pastagem apresentava uma baixa proporção de material morto (excetuando-se o T3, que desde o início do experimento já começou a acumular material morto nas bases das touceiras), sendo a produção de novas folhas e novos perfilhos os principais responsáveis pelo aumento de fitomassa da pastagem. Korte et al. (1982) observaram declínio na taxa de acúmulo líquido de forragem em azevém perene, quando baixas frequências e intensidades de pastejo foram sucessivas durante o verão, o que promoveu o acúmulo de material morto no dossel.

Os maiores valores de TAL no P1 podem ser parcialmente explicados pelos ângulos foliares médios e pela IL. Os ângulos foliares médios, nesse período, foram mais elevados (folhas mais eretas), o que, como já citado, permitia uma maior penetração da radiação no dossel, favorecendo assim, a TAL. Com relação à IL, os tratamentos 2 e 3 foram os principais responsáveis pelas maiores TAL no P1, pois nesse período, T2 e T3 já apresentavam valores médios de IL de 85,8 e 90,7\% (média dos oito ciclos entre os dias 1 e 11), respectivamente, enquanto que o T1 apresentava 75,4\%. 
Parsons \& Penning (1988), avaliando diferentes intervalos de pastejo em azevém perene, observaram que, ao passar de intervalos curtos (12-13 dias), para médios (19-23 dias) e longos (30-34 dias), apesar do aumento na quantidade de matéria seca, não houve um aumento na taxa média de acúmulo líquido, o que suporta os resultados de maiores TAL observadas no P1 no presente estudo.

Analogamente aos resultados de IL, os resultados de TAL para os períodos de avaliação, sugerem que uma opção para a intensificação de sistemas de produção animal em pastagens, seria a utilização de pastos de capim Tanzânia sob lotação rotacionada, irrigadas e com os níveis de fertilização utilizados, com períodos de descanso menores que 33 dias, já que a partir do $22^{\circ}$ dia da rebrota, não há diferença na TAL. Segundo esses resultados, períodos de rebrotas superiores a 22 dias podem promover, principalmente sob menores intensidades de pastejo, um excesso de acúmulo de material morto no dossel e, consequientemente, perdas de forragem, que poderia ser consumida pelos animais. É necessário, portanto, a avaliação desses sistemas com períodos de descanso menores que os atualmente utilizados (em torno de 30 dias), com uma maior quantidade de ciclos de pastejo, com o intuito de verificar a persistência e perenidade da pastagem, quando submetida a altas intensidades de pastejo. 


\section{CONCLUSÕES}

Com base nos resultados obtidos no presente trabalho, pode-se concluir que:

- A fase da rebrota (dia pós-pastejo) não afetou as taxas líquidas de fotossíntese foliar. Essas taxas foram regidas pela categoria da folha, expressa principalmente pela sua idade.

- A maior intensidade de pastejo (menor resíduo pós-pastejo), alterou a estrutura da pastagem no que diz respeito à arquitetura do dossel, evidenciada pela redução nos ângulos foliares médios (folhas mais planas) ao longo das estações, resultando em maior interceptação luminosa por unidade de área foliar.

. Pastagens de capim Tanzânia com folhagem predominantemente ereta, proporcionam maiores acúmulos líquidos de forragem, em função do melhor aproveitamento da luz incidente.

- Os IAFs críticos medidos sugerem a necessidade de períodos de descanso relativamente curtos em pastos de capim Tanzânia, submetidos a pastejo intensivo sob lotação rotacionada e irrigação.

- A maior intensidade de pastejo não causou depressão no vigor de rebrota medido como a taxa de acúmulo líquido de forragem. É necessário, entretanto, avaliar a persistência e perenidade de pastagens de capim Tanzânia manejadas com altas intensidades de pastejo, a longo prazo.

- O manejo da pastagem em sistemas intensivos de produção, deve buscar níveis de resíduos pós-pastejo que permitam altas taxas iniciais de acúmulo líquido de forragem. 


\section{REFERÊNCIAS BIBLIOGRÁFICAS}

AGATA, W.; KAWAMITSU, Y.; HAKOIAMA, S. et al. Characteristics of Photosynthesis, Transpiration and water use efficiency of $\mathrm{C}_{3}$ e $\mathrm{C}_{4}$ grasses leaves. In: INTERNATIONAL GRASSLAND CONGRESS, 15., Kioto, 1985. Proceedings. Kioto: Kyushu University, 1985. p. 347-349.

AGUIAR, A.P.A. Possibilidades de intensificação do uso da pastagem através de rotação sem ou com o uso mínimo de fertilizantes. In: SIMPÓSIO SOBRE MANEJO DA PASTAGEM, 14., Piracicaba, 1997. Anais. Piracicaba: FEALQ, 1997. p. 85-138.

AGUIAR, A.P.A. Uso de forrageiras do grupo Panicum em pastejo rotacionado para vacas leiteiras. In: SIMPÓSIO DE FORRAGICULTURA E PASTAGENS TEMAS EM EVIDÊNCIA, 1., Lavras, 2000. Anais. Lavras: UFLA, 2000. p. 69147.

ALVIM, M.J.; BOTREL, M. A.; NOVELLY, P.E. Produção de gramíneas tropicais e temperadas, irrigadas na época da seca. Revista da Sociedade Brasileira de Zootecnia, v. 15, n. 5, p. 384-392, 1986.

ARONOVICH, S. O capim Colonião e outros cultivares de Panicum maximum Jacq.: introdução e evolução do uso no Brasil. In: SIMPÓSIO SOBRE MANEJO DA PASTAGEM, 12., Piracicaba, 1995. Anais. Piracicaba: FEALQ, 1995. p. 1-20. 
BARBOSA, M.A.A.F.; NASCIMENTO JÚNIOR, D.; CECATO, U. et al. Desempenho de garrotes em capim Tanzânia (Panicum maximum Jacq. cv. Tanzânia) com diferentes ofertas de forragem (compac disc). In: SIMPÓSIO PECUÁRIA 2000 PERSPECTIVAS PARA O III MILÊNIO, 1., Pirassununga, 2000. Anais. Pirassununga: USP, FZEA, 2000.

BERNARDES, M.S. Fotossíntese no dossel das plantas cultivadas. In: CASTRO, P.R.C.; FERREIRA, S.O.; YAMADA, T. (Ed.). Ecofisiologia da produção agrícola. Piracicaba: POTAFOS, 1987. p. 13-48.

BERNARDES, M.S.; LIMA, S.F.F. Densidade populacional, disposição e direção de linhas de plantio, manejo da copa: a luz como fator essencial. In: CURSO DE ATUALIZAÇÃO EM RELAÇÕES SOLO-PLANTA-ATMOSFERA, Piracicaba, 2000. Piracicaba: ESALQ, 2000. 55 p.

BOTREL, M.A.; ALVIM, M.J.; XAVIER, D.F. Efeito da irrigação sobre algumas características agronômicas de cultivares de capim-elefante. Pesquisa Agropecuária Brasileira, v. 26, p. 1731-1736, 1991.

BRASIL. Ministério da Agricultura, do Abastecimento e da Reforma Agrária. Agricultura brasileira: Desempenho em 1993. Brasília, 1994. Pecuária: p. 20-31. BROUGHAM, R. W. Interception of light by the foliage of pure and mixed stands of pasture plants. Australian Journal Agricultural Research, v. 9, p. 39-52. 1958.

BROWN, R.H. Photosynthesis and growth of pastures as influenced by defoliation. In: SOUTHERN PASTURE AND FORAGE CROP IMPROVEMENT CONFERENCE, 34., 1987. Clemson: USDA-ARS, 1987. p. 34-35.

BROWN, R.H.; BLASER, R.E. Leaf area index in pasture growth. Herbage Abstracts, V. 38, p. 1-9, 1968.

BROWN, R.H.; COOPER, R.B.; BLASER, R.E. Effects of leaf age on efficiency. Crop Science, v. 6, p. 206-209, 1966.

BUENO, F.O.; CARNEVALLI, R.A.; UEBELE, M.C. et al. Uso de índice de área foliar e interceptação luminosa como critério para determinação do manejo do pastejo para o capim Mombaça (Panicum maximum Jacq.) - Perdas de pastejo (compact disc). In: SIMPÓSIO INTERNACIONAL DE INICIAÇÃO 
CIENTÍFICA DA UNIVERSIDADE DE SÃO PAULO, 9., Piracicaba, 2001. Anais. Piracicaba: ESALQ, 2001.

BURT, R.L. Growth and development of buffel grass (Cenchrus ciliaris). Australian Journal of Experimental Agriculture and Animal Husbandry, v. 8, p. 712-719, 1968.

BURTON, G.W.; JACKSON, J.E.; KNOX, F.E. The influence of light reduction upon the production, persistence, and chemical composition of Coastal Bermudagrass, Cynodon dactylon. Agronomy Journal, v. 51, p. 537-542, 1959.

CANTO, M.W.; CECATO, U.; PETERNELli, M. et al. Efeito da altura do capimTanzânia diferido nas características da pastagem no período de inverno. Revista Brasileira de Zootecnia, v. 30, n. 4, p. 1186-1193, 2001.

CARNEVAlli, R.A.; SILVA, S.C.; CARVALHO, C.A.B. et al. Desempenho de ovinos e respostas de pastagens de Florakirk (Cynodon spp.) submetidas a regimes de desfolha sob lotação contínua. Boletim de Indústria Animal, v. 57, n. 1, p. 53$63,2000$.

CARNEVAlli, R.A.; SILVA, S.C.; CARVALHO, C.A.B. et al. Desempenho de ovinos e respostas de pastagens de Coastcross (Cynodon spp.) submetidas a regimes de desfolha sob lotação contínua. Pesquisa Agropecuária Brasileira, v. 36, n. 6, p. 919-927, 2001b.

CARNEVALLI, R.A.; SILVA, S.C.; FAGUNDES, J.L. et al. Desempenho de ovinos e respostas de pastagens de Tifton 85 (Cynodon spp.) sob lotação contínua. Scientia Agricola, v. 58, n. 1, p. 7-15, $2001 \mathrm{a}$.

CHACÓN-MORENO, E.; RADA, F.; SARMIENTO, G. Intercambio gaseoso, nitrógeno foliar y optimación en el manejo de Panicum maximum (tipo común) sometido a diferentes frecuencias de corte. Turrialba, v. 45, n. 1-2, p. 19-26, 1995.

CHASE, A. Grasses of Brazil and Venezuela. Agriculture in the America, v. 4, p.123-126, 1944.

COOPER, J.P. Potential production and energy conversion in temperate and tropical grasses. Herbage Abstracts, v. 40, p. 1-15, 1970. 
COOPER, J.P.; TAINTON, N.M. Light and temperature requirements for the growth of tropical and temperate grasses. Herbage Abstracts, v. 38, n. 3, p. 167-176, 1968.

COOPER, J.P.; WILSON, D. Variation in photosynthetic rate in Lolium. In: INTERNATIONAL GRASSLAND CONGRESS, 11., Surfers Paradise, 1970. Proceedings. Santa Lucia: University of Queensland Press, 1970. p. 522-527.

CORSI, M. Espécies forrageiras para pastagem. In: Pastagens: Fundamentos da exploração racional. Piracicaba: FEALQ, 1994. p. 225-254.

CORSI, M; NASCIMENTO jr., D. Princípios de fisiologia e morfologia de plantas forrageiras aplicados ao manejo das pastagens. In: Pastagens - Fundamentos da Exploração Racional. Piracicaba: FEALQ, 1994. p. 15-48.

CORSI, M.; SANTOS, P.M. Potencial de produção do Panicum maximum. In: SIMPÓSIO SOBRE MANEJO DA PASTAGEM, 12., Piracicaba, 1995. Anais. Piracicaba: FEALQ, 1995. p. 275-303.

COSTA, C.; MONTEIRO, A.L.G. Alfafa como forrageira para corte e pastejo In: SIMPÓSIO SOBRE ECOSSISTEMAS DE PASTAGENS, 3., Jaboticabal, 1997. Anais. Jaboticabal: FCAV, 1997. p. 297-317.

COSTA, N.L.; TOWNSEND, C.R.; MAGALHÃES, J.A.; PEREIRA, R.G.A. Avaliação agronômica sob pastejo de Paspalum atratum BRA-009610. Pasturas Tropicales, v. 21, n. 2, p. 71-74, 1999.

DAVIES, A. Leaf tissue remaining after cutting and regrowth in perennial ryegrass. Journal of Agricultural Science, v. 82, p. 165-172, 1974.

DIAS FILHO, M.B. Efeito do estresse hídrico em alguns aspectos agronômicos e fisiológicos do capim Tobiatã (Panicum maximum Jacq. cv. Tobiatã) em casa de vegetação. Piracicaba, 1986. 103 p. Dissertação (Mestrado) - Escola Superior de Agricultura "Luiz de Queiroz", Universidade de São Paulo.

DONALD, C.M. In search of yield. The Journal of the Australian Institute of Agricultural Science, v. 28, n. 3, p. 171-178, 1962.

DUNCAN, W.G. Leaf angles, leaf area, and canopy photosynthesis. Crop Science, v.11, p. 482-485. 
DYER, M.I.; ACRA, M.A.; WANG, G.M. et al. Source-sink carbon relations in two Panicum coloratum ecotypes in response to herbivory. Ecology, v. 72, n. 4, p.1472-1483, 1991.

Escola Superior de Agricultura Luiz de Queiroz. Base de dados da estação meteorológica automatizada:área de Física e Metereoologia - DCE - ESALQ USP. http://ce.esalq.usp.br/automatica/pagina5.html (21 jan./2002).

EUCLIDES, V.P.B.; MACEDO, M.C.M.; OLIVEIRA, M.P. Avaliação de ecotipos de Panicum maximum sob pastejo em pequenas parcelas. In: REUNIÃO ANUAL DA SOCIEDADE BRASILEIRA DE ZOOTECNIA, 32., Brasília, 1995. Anais. Brasília: SBZ, 1995. p. 97-99

EUCLIDES, V.P.B.; MACEDO, M.C.M.; VALÉRIO, J.R.et al. Cultivar massai (Panicum maximum) uma nova opção forrageira: características de adaptação e produtividade (compact disc). In: REUNIÃO ANUAL DA SOCIEDADE BRASILEIRA DE ZOOTECNIA, 37., Viçosa, 2000. Anais. Viçosa: SBZ, 2000.

FAGUNDES, J.L. Efeito de intensidades de pastejo sobre o índice de área foliar, interceptação luminosa e acúmulo de forragem em pastagens de Cynodon spp. Piracicaba, 1999. 69 p. Dissertação (Mestrado) - Escola Superior de Agricultura “Luiz de Queiroz”, Universidade de São Paulo.

FAGUNDES, J.L.; SILVA, S.C.; PEDREIRA, C.G.S. et al. Índice de área foliar, interceptação luminosa e acúmulo de forragem em pastagens de Cynodon spp. sob diferentes intensidades de pastejo. Scientia Agricola, v. 56, n. 4, p. 1141-1150, 1999.

FARIA, V.P. Efeito da maturidade da planta e diferentes tratamentos sobre a ensilagem do capim elefante (Pennisetum purpureum) var. Napier. Piracicaba, 1971. 78 p. Tese (Doutorado) - Escola Superior de Agricultura "Luiz de Queiroz", Universidade de São Paulo.

FARIA, V.P.; PEDREIRA, C.G.S.; SANTOS, F.A.P. Evolução do uso de pastagens para bovinos. In: SIMPÓSIO SOBRE MANEJO DA PASTAGEM, 13., Piracicaba, 1996. Piracicaba: FEALQ, 1996. p. 1-14. 
FNP Consultoria e Comércio: anuário da pecuária brasileira. São Paulo, 2001. 447 p.

GIFFORD, R.M.; THORNE, J.H.; HITZ, W.D. et al. Crop productivity and photoassimilate partitioning. Science, v. 225, n. 4664, p. 801-808, 1984.

GOMIDE, J.A. Fisiologia e manejo de plantas forrageiras. Revista da Sociedade Brasileira de Zootecnia, v. 2, p. 17-26. 1973a.

GOMIDE, J.A. Fisiologia do crescimento livre de plantas forrageiras. In: SIMPÓSIO SOBRE MANEJO DA PASTAGEM, 1., Piracicaba, 1973. Piracicaba: FEALQ, 1973b. p. 83-93.

GUELFI FILHO, H. Efeito da irrigação sobre o capim colonião (Panicum maximum Jacq.). O Solo, v. 68, n. 1, p. 12-15, 1876.

HAY, R.K.M.; WALKER, A.J. Interception of solar radiation by the crop canopy. In: HAY, R.K.M.; WALKER, A.J. An introduction to the physiology of crop yield. New York: Longman Scientific \& Technical, 1989. p. 8-30.

HAYNES, R.J. Competitive aspects of the grass legume association. Advances in Agronomy, v. 15, p. 1- 117, 1980.

HERLING, V.R.; RODRIGUES, L.R.A.; NOGUEIRA FILHO, C.G. et al. Efeitos de níveis de nitrogênio sobre os cultivares Colonião e Centenário (Panicum maximum Jacq.). I. Características fisiológicas. In: REUNIÃO ANUAL DA SOCIEDADE BRASILEIRA DE ZOOTECNIA, 32., Brasília, 1995. Anais. Brasília: SBZ, 1995. p. 71-73.

HODGINS, R.; VAN HUYSTEE, R.B. Porphyrin metabolism in chill stressed maize (Zea mays L.). Journal of Plant Physiology, n. 126, p. 257-268, 1986.

HODGSON, J. Grazing management: Science into practice. London: Longman Scientific and Technical, 1990.

HUMPHREYS, L.R. Subtropical grass growth. II. Effects of variation in leaf area index in the field. Queenland Journal of Agricultural and Animal Sciences, v. 23, n. 4, p. 337-358, 1966.

HUMPHREYS, L.R. Tropical pasture utilisation. Cambridge: Cambridge University Press, 1991. 206 p. 
HYDER, D.N. Defoliation in relation to vegetative growth. In: YOUNGNER, V.B.; McKELL, C.M. (Ed.) The biology and utilization of grasses. New York: Academic Press, 1972. p. 304-317.

JACQUES, A.V.A. Fisiologia do crescimento de plantas forrageiras. In: SIMPÓSIO SOBRE MANEJO DA PASTAGEM, 1., Piracicaba, 1973. Piracicaba: FEALQ, 1973. p. 95-101.

JANK, L. Potencial do gênero Panicum. In: SIMPÓSIO BRASILEIRO DE FORRAGEIRAS E PASTAGENS, Campinas, 1994. Anais. Campinas: CBNA, 1994. p. 25-31.

JANK, L. Melhoramento e seleção de variedades de Panicum maximum. In: SIMPÓSIO SOBRE MANEJO DA PASTAGEM, 12., Piracicaba, 1995. Anais. Piracicaba: FEALQ, 1995. p. 21-58.

JEWISS, O.R.; WOLEDGE, J. The effect of age on the rate apparent photosynthesis in leaves of Tall Fescue (Festuca arundinacea Schreb.). Annals of Botany, v. 31, n.24, p. 661-671, 1967

KEPHART, K.D.; BUXTON, D.R., TAYLOR, S.E. Growth of $\mathrm{C}_{3}$ and $\mathrm{C}_{4}$ Perennial Grasses under Reduced Irradiance. Crop Science, v. 32, p. 1033-1038, 1992.

KIDD, D.D. The effect of intensive sheep stocking over a five-year period on the development and production of the sward. I. Sward structure and botanical composition. Journal of the British Grassland Society, v. 21, p. 284-288, 1966.

KING, J.; SIM, E.M.; GRANT, S.A. Photosynthetic rate and carbon balance of grazed ryegrass pastures. Grass and Forage Science, v. 39, p. 81-92, 1984.

KORTE, C.J.; WATKIN, B.R.; HARRIS, W. Use of residual leaf area index and light interception as criteria for spring-grazing management of a ryegrass-dominant pasture. New Zealand Journal of Agricultural Research, v. 25, p. 309-319, 1982.

LEMAIRE, G.; CHAPMAN, D. Tissue flows in grazed plant communities. In: HODGSON, J.; ILliUS, A.W. (Ed.) The ecology and management of grazing systems. Guilford: CAB International, 1996. p. 3-36.

LOOMIS, R.S.; WILLIAMS, W.A. Productivity and the morphology of crop stands: patterns with leaves. In: EASTIN, J.D.; HASKINS, F.A.; SULLIVAN, C.Y. et al. (Ed.) Physiological aspects of crop yield. Madison: ASA,CSSA,SSA, 1969. p. 27-47. 
LUDLOW, M.M. Photosynthesis and dry matter production in $\mathrm{C}_{3}$ and $\mathrm{C}_{4}$ pasture plants with special emphasis on tropical $\mathrm{C}_{3}$ legumes and $\mathrm{C}_{4}$ grasses. Australian Journal of Plant Physiology, v. 12, p. 557-572, 1985.

LUDLOW, M.M.; WILSON, G.L. Photosynthesis of tropical pasture plants. I. Illuminance, carbon dioxide concentration, leaf temperature, and leaf-air vapour pressure difference. Australian Journal Biological Science, v. 24, p. 449-470, 1971.

MARASCHIN, G.E. Sistemas de pastejo 1. In: CONGRESSO BRASILEIRO DE PASTAGENS'86; SIMPÓSIO SOBRE MANEJO DA PASTAGEM, 8., Piracicaba, 1986. Anais. Piracicaba: FEALQ, 1986. p. 261-290.

MARSHALL, C. Physiological aspects of pasture growth. In: SNAYDON, R.W. (Ed.) Managed grasslands: analytical studies ecossystems of the world. vol. 17-B. Amsterdam: Elsevier Science, 1987. p. 29-46.

MARTINS, C.E.; CÓSER, A.C.; ALVIM, M.J. et al. Irrigação: uma estratégia de intensificação da produção de leite a pasto. In: SIMPÓSIO DE FORRAGICULTURA E PASTAGENS - TEMAS EM EVIDÊNCIA, 1., Lavras, 2000. Anais. Lavras: UFLA, 2000. p. 311-356.

MATCHES, A.G. Plant response to grazing: a review. Journal of Production Agriculture, v. 5, n. 1, p. 1-7, 1992.

MAXWELL, T.J.; TREACHER, T.T. Decision rules for grassland management. In: POLLOT, G.E. (Ed.) Efficient sheep production from grass. British Grassland Society. 1987. p. 67-78. (Occasional Symposium, 21)

McCOSKER, T.H.; TEITZEL, J.K. A review of guinea grass (Panicum maximum) for the wet tropics of Australia. Tropical Grasslands, v. 9, n. 3, p. 177-190, 1975.

MELLO, A.C.L.; SANTOS, P.M.; PEDREIRA, C.G.S. et al. Phothosynthetic light response of Tanzania grass under four levels of leaf temperature. In: INTERNATIONAL GRASSLAND CONGRESS, 19., São Pedro, 2001. Proceedings. Piracicaba: FEALQ, 2001a. p. 73-74. 
MELLO, A.C.L.; LOURENÇO, L.F.; MEDEIROS, H.R. et al. Dinâmica do índice de área foliar de capim Tanzânia em função do fotoperíodo e da temperatura do ar. In: CONGRESSO BRASILEIRO DE FISIOLOGIA VEGETAL, 8., Ilhéus, 2001. Anais. Ilhéus: SBFV, 2001b. p. 223.

MÜLLER, M.S. Desempenho de Panicum maximum Jacq. (cv. Mombaça) em pastejo rotacionado, sob sistema de irrigação por pivô central, na região de cerrado. Piracicaba, 2000. 101 p. Dissertação (Mestrado) - Escola Superior de Agricultura “Luiz de Queiroz”, Universidade de São Paulo.

OBERHUBER, W.; EDWARDS G.E. Temperature dependence of linkage of quantum yield of photosystem II to $\mathrm{CO}_{2}$ fixation in $\mathrm{C}_{4}$ and $\mathrm{C}_{3}$ plants. Plant Physiology, v.101, p. 507-512, 1993.

PARSONS, A.J.; PENNING, P.D. The effect of the duration of regrowth on photosynthesis, leaf death and the average rate of growth in a rotationally grazed sward. Grass and Forage Science, v. 43, p. 15-27, 1988.

PARSONS, A.J.; ROBSON, M.J. Seasonal changes in the phsylogy of S24 perennial ryegrass (Lolium perenne L.). 3. Partitioning of assimilates between root and shoot during the transition from vegetative to reproductive growth. Annals of Botany, v.48, p. 733-744, 1981.

PARSONS, A.J.; LEAFE, E.L.; COLLET, B. et al. The physiology of grass production under grazing. I. Characteristics of leaf and canopy photosynthesis of continuouslygrazes swards. Journal of Applied Ecology, v. 20, p. 117-126. 1983.

PEARCE, R.B.; BROWN, R.H.; BLASER, R.E. Relationships between leaf area index, light interception and net photosynthesis in orchardgrass. Crop Science, v. 5, p.553-556, 1965.

PENATI, M.A. Estudo do desempenho animal e produção do capim Tanzânia (Panicum maximum Jacq.) em um sistema rotacionado de pastejo sob irrigação em três níveis de resíduo pós-pastejo. Piracicaba, 2002. 117 p. Tese (Doutorado) - Escola Superior de Agricultura “Luiz de Queiroz”, Universidade de São Paulo.

POWLES, S.B. Photoinhibition of photosynthesis induced by visible light. Annual Reviews of Plant Physiology, v. 35, p. 15-44, 1984 
RHODES, I. The relationship between productivity and some components of canopy structure in ryegrass (Lolium spp.). Journal of Agricultural Science, v. 37, p. 283292. 1971.

RHODES, I. Relationship between canopy structure and productivity in herbage grasses and its implication for plant breeding. Herbage Abstracts, v.43, p.129-133, 1973.

RHODES, I.; MEE, S.S. Changes in dry matter yield associated with selection for canopy characters in ryegrass. Grass and Forage Science, v. 35, p. 35-39. 1980.

ROCHA, G.L. Ecossistemas de pastagens: - aspectos dinâmicos. Piracicaba: SBZ;FEALQ, 1991. 391 p.

RODRIGUES, L.R.A.; RODRIGUES, T.J.D. Ecofisiologia de plantas forrageiras. In: CASTRO, P.R.C.; FERREIRA, S.O.; YAMADA, T. (Ed.) Ecofisiologia da produção Agrícola. Piracicaba: POTAFOS, 1987. p. 203-230.

ROLIM, F. de A. Estacionalidade de produção de forrageiras. In: PEIXOTO, A.M.; MOURA, J.C.; FARIA, V.P. (Ed.) Pastagens - fundamentos da exploração racional. Piracicaba: FEALQ, 1994. p. 533-565.

SANCHEZ, P.A.; SALINAS, J.G. Low input technology for managing oxisols and ultisols in Tropical America. Advances in Agronomy, v. 34, p. 279-405, 1981.

SANTOS, P.M.; CORSI, M.; BALSALOBRE, M.A.A. Efeito da frequiência de pastejo e da época do ano sobre a produção e a qualidade em Panicum maximum cvs. Tanzânia e Mombaça. Revista Brasileira de Zootecnia, v. 28, n. 2, p. 244-249, 1999.

SAS INSTITUTE. SAS user's guide: realese. 6.03. Cary, 1988. 1028 p.

SHEEHY, J.E.; COOPER, J.P. Light interception, photosynthetic activity, and crop growth rate in canopies of six temperature forage grasses. Journal of Applied Ecology, v. 10, p. 239-250, 1973.

SILVA, S.C. Condições edafo-climáticas para a produção de Panicum sp.. In: SIMPÓSIO SOBRE MANEJO DA PASTAGEM, 12., Piracicaba, 1995. Anais. Piracicaba: FEALQ, 1995. p. 129-146. 
SILVA, S.C.; PEDREIRA, C.G.S. Princípios de ecologia aplicados ao manejo da pastagem. In: SIMPÓSIO SOBRE ECOSSISTEMAS DE PASTAGENS, 3., Jaboticabal, 1997. Anais. Jaboticabal: Funep, 1997. p. 1-12.

TAIZ, L.; ZEIGER, E. Plant physiology. 2 ed. Sunderland: Sinauer Associates, 1998. $792 \mathrm{p}$.

VERHAGEN, A.M.W.; WILSON, J.H., BRITTEN, E.J. Plant production in relation to foliage illumination. Annal of Botany, v. 27, n. 108, p. 626-640. 1963.

WANG, C.Y. A critique of the heat unit approach to plant response studies. Ecology, v. 41, n. 4, p. 785-790, 1960.

WARD, C.Y.; BLASER, R.E. Carboydrate Food Reserves and Leaf Area in Regrowht of Orchardgrass. Crop Science, v. 1, p. 366-370. 1961.

WARREN-WILSON, J. Influence of spatial arrangement of foliage area on light interception and pasture growth. In: INTERNATIONAL GRASSLAND CONGRESS, 8., Berkshire, 1961. Proceedings. Berkshire: Alden Press, 1961. p. 275-279.

WATSON, D.J. Comparative physiological studies on the growth of field crops. I. Variation in net assimilation rate and leaf area between species and varieties, and within and between years. Annals of Botany, v.11, p. 41-76, 1947.

WELLES, J.M.; NORMAN, J.M. Instrument for Indirect Measurement of Canopy Architecture. Agronomy Journal, v. 83, p. 818-825, 1991.

WILSON, J.R. Influence of temperature and nitrogen on growth, photosynthesis and accumulation of non-structural carbohydrate in a tropical grass, Panicum maximum var. trichoglume. Netherland Journal of Agricultural Science, v. 23, p. 48-61, 1975.

ZELITCH, I. The close relationship between net photosynthesis and crop yield. BioScience, v. 32, p. 796-802, 1982. 